\title{
'...FINDING A SMOOTHER PEBBLE OR PRETTIER SHELL THAN ORDINARY' - NON-UTILITARIAN ARTEFACTS IN THE UPPER PALAEOLITHIC - A CASE STUDY FROM MOGYORÓSBÁNYA (TRANSDANUBIA, HUNGARY)
}

\author{
ANDRÁS MARKÓ*-ALFRÉD DULAI**-VIOLA DOBOSI* \\ * Department of Archaeology, Hungarian National Museum \\ 14-16, Múzeum krt, H-1088 Budapest, Hungary \\ markoa@hnm.hu,t.dobosi.viola@hnm.hu \\ ** Department of Palaeontology and Geology, \\ Hungarian Natural History Museum \\ 2, Ludovika tér, H-1083 Budapest, Hungary \\ dulai.alfred@nhmus.hu
}

\begin{abstract}
During the excavations of the Upper Palaeolithic site at Mogyorósbánya several non-utilitarian artefacts were found. Beside the earlier published piece of fossil resin (amber) and lumps of red ochre, more than one hundred Palaeogene and Neogene fossil molluscs, large foraminifers, corals and trace fossils from at least three different geological formations, as well as numerous fragments of phyllite were documented.

Pebbles of this soft shale were most probably collected from the alluvium of the Danube river. The majority of the pieces show clear traces of scraping and along the periphery of the largest artefact rhythmic incisions are visible. Even if this piece is not a ready-made object, it can be compared to the limestone and sandstone pebbles found on the Epigravettian site of Pilismarót-Pálrét. Another interesting artefact of unknown function is a carefully shaped but strongly fragmented piece with sharp edge.

Fossils of the Eocene Epoch were easily accessible in the region of Mogyorósbánya, while the nearest fossiliferous outcrops of the Oligocene and Pannonian sediments are found $15-17 \mathrm{~km}$ in south-eastern direction from the site.

Few gastropod shells show unambiguous traces of human modification. Typically, among the 16 Melanopsis fossils found in a single square meter only three pieces were manufactured. On the other hand, the majority of the Dentalium and worm tube fragments were cut and their surfaces show intense rounding and shine.

The not modified Nummulites, corals and large internal casts of gastropods were most probably collected by Prehistoric humans because of their unusual form. This interesting group of the Mogyorósbánya artefacts and are compared to the fossils published from the Pilisszántó I rockshelter and to the not modified fossils from Moravia and Romania.
\end{abstract}

Keywords: fossil mollusc, coral, phyllite, perforation, spatial distribution

Non-utilitarian artefacts are relatively rare elements of the Palaeolithic assemblages in Hungary. Since the last review of these unusual pieces ${ }^{1}$ only short specialised papers have been published. ${ }^{2}$ In the present study the Palaeogene and Neogene fossils and phyllite artefacts excavated in the Mogyorósbánya site complex are analysed, with a focus on the taxonomic classification and source identification of the fossil remains, the human selection and manufacture of the pieces, as well as their spatial distribution in the excavated trenches.

On the Pebble Gravettian site of Mogyorósbánya-Újfalusi-dombok three discrete settlement units were excavated by V. Dobosi between 1984 and 2009. ${ }^{3}$ The in situ documented part of spot I and II reached 40 and 30 square meters, while spot III is the largest Upper Palaeolithic settlement unit in Hungary with more than 300 excavated square meters. The rich lithic industry, the remarkable large mammal fauna, a piece of fossil resin (amber)

\footnotetext{
${ }^{1}$ Dobosi 1985.

${ }^{2}$ Magyar 1991a; MagYar 1991b; FöLdVÁRI 1992; Dulai 2007.
}

${ }^{3}$ Doвоsi 1992; DовоSI 2002; Doвоsi 2011; DовоSI 2016. 
and lumps of red ochre, ${ }^{4}$ documented in the $\mathrm{h}_{2}$ embryonic soil of the Hungarian loess stratigraphy ${ }^{5}$ and associated by two radiocarbon dates ${ }^{6}$ make possible the complex analysis of this site.

During the surface collections and the excavations 104 Palaeogene and Neogene molluscs, foraminifers and corals, as well as trace fossils were found (Table 1). The richest assemblage with 90 fossils and three fragments of burrow infill (cemented sand) were excavated in settlement spot III. After the successful refit experiments (Table 2) we estimate that 83 pieces were introduced to the excavated part of this settlement unit. The distribution map of the fossils shows three concentrations (Fig. 1.1) in the southern, middle and the south-eastern part of the excavated surface, respectively. The majority of the pieces were found, however, in a loose scatter.

Table 1.

Mogyorósbánya: Palaeogene and Neogene fossils

\begin{tabular}{|c|c|c|c|c|c|}
\hline & spot I & spot II & spot III & surface & Total \\
\hline \multicolumn{6}{|l|}{ Eocene fossils } \\
\hline Nummulites brongniarti (d'Archiac \& Haime, 1853) & & & 2 & & 2 \\
\hline Isis sp. & 1 & & & & 1 \\
\hline Trochosmilia sp. & & & 2 & & 2 \\
\hline Circophyllia sp. & & & 1 & & 1 \\
\hline Turritella granulosa (Deshayes, 1832) & & 1 & 2 & 1 & 4 \\
\hline Diastoma roncanum (Brongniart, 1823) & & & 1 & & 1 \\
\hline Cerithium subcorvinum (Oppenheim, 1894) & & & 2 & & 2 \\
\hline Tympanotonos calcaratus (Brongniart, 1823) & 1 & & 2 & & 3 \\
\hline Tympanotonos diaboli (Brongniart 1823) & & 1 & & 1 & 2 \\
\hline Tympanotonos hungaricus (Zittel, 1862) & & & 1 & & 1 \\
\hline Tympanotonos sp. & & & 2 & & 2 \\
\hline Ampullina perusta (Defrance, 1823) & & & 1 & & 1 \\
\hline Ampullina sp. & & & 1 & & 1 \\
\hline Ancilla propinqua (Zittel, 1853) & & & 1 & & 1 \\
\hline Conus parisiensis (Deshayes, 1865) & & & 1 & & 1 \\
\hline Vermetus serpuloides (Deshayes, 1864) & & & & 1 & 1 \\
\hline Eocene fossils total & 2 & 2 & 19 & 3 & 26 \\
\hline \multicolumn{6}{|l|}{ Oligocene fossils } \\
\hline Tympanotonos margaritaceus (Brocchi, 1814) & & & 24 & & 24 \\
\hline Aporrhais callosa (Telegdi-Roth 1914) & & & 1 & & 1 \\
\hline Dentalium kickxi (Nyst, 1843) & & 1 & 8 & & 9 \\
\hline Oligocene fossils total & & 1 & 33 & & 34 \\
\hline \multicolumn{6}{|l|}{ Pannonian fossils } \\
\hline Melanopsis fossilis (Gmelin, 1791) & & & 3 & & 3 \\
\hline Melanopsis impressa (Krauss, 1852) & 1 & & 20 & & 21 \\
\hline Melanopsis sp. & & & 2 & & 2 \\
\hline Pannonian fossils total & $\mathbf{1}$ & & 25 & & 26 \\
\hline \multicolumn{6}{|l|}{ Fossils from not identified epoch } \\
\hline Bittium sp. & & & 2 & & 2 \\
\hline Gastropoda indet. & & 1 & 3 & & 4 \\
\hline Glycymeris sp. & & & & 1 & 1 \\
\hline Ostrea sp. & & & 4 & & 4 \\
\hline worm tube fragments & & & 4 & & 4 \\
\hline burrow infill & & & 3 & & 3 \\
\hline from not identified epoch total & & 1 & 16 & 1 & 18 \\
\hline Total & 3 & 4 & 93 & 4 & 104 \\
\hline
\end{tabular}

${ }^{4}$ FÖLDVÁRI 1992; MiHÁLY 2011.

${ }^{5}$ PÉCSI 1975.
${ }^{6}$ The charcoal samples were collected from fireplaces during the excavations of settlement spots II (Deb-1169: 19.930 \pm 300 B.P.) and III (Deb-9673: 19.000 \pm 250 B.P.): DoBosi 1992; DoBosISZÁNTÓ 2003. 
Table 2.

Mogyorósbánya III: conjoined fragments found in the cultural layer

\begin{tabular}{|c|c|c|c|c|c|}
\hline nr. & Inv. nr. & species & trench & distance of the elements & \\
\hline 1 & $\begin{array}{l}\mathrm{Pb} .92 / 038 \\
\mathrm{~Pb} .92 / 046\end{array}$ & Cerithium subcorvinum & $\begin{array}{l}\text { trench } \mathrm{X} \text {, square } 2 \\
\text { trench } \mathrm{X} \text {, square } 3\end{array}$ & $125 \mathrm{~cm}$ & Fig. 13.2 \\
\hline 2 & $\begin{array}{l}\mathrm{Pb} .88 / 1021 \\
\mathrm{~Pb} .88 / 1046 \\
\end{array}$ & Dentalium kickxi & $\begin{array}{l}\text { trench } \mathrm{O} \\
\text { trench } \mathrm{O} \text {, square } 30\end{array}$ & excavation damage? & Fig. 5.12 \\
\hline 3 & $\begin{array}{l}\mathrm{Pb} .92 / 18 \\
\mathrm{~Pb} .92 / 57\end{array}$ & Turritella granulosa & $\begin{array}{l}\text { trench } X,-100 \mathrm{~cm} \\
\text { trench } X, \text { square } 4\end{array}$ & excavation damage? & \\
\hline 4 & $\begin{array}{l}\mathrm{Pb} .2000 / 612 \\
\mathrm{~Pb} .2000 / 659 \\
\end{array}$ & Tympanotonos margaritaceus & $\begin{array}{l}\text { trench } \alpha, \text { square } 17 \\
\text { trench } \alpha, \text { square } 17\end{array}$ & $40 \mathrm{~cm}$ & Fig. 8.1 \\
\hline 5 & $\begin{array}{l}\mathrm{Pb} .2000 / 666 \\
\mathrm{~Pb} .2000 / 667 \\
\end{array}$ & Tympanotonos margaritaceus & $\begin{array}{l}\text { trench } \alpha, \text { square } 18 \\
\text { trench } \alpha, \text { square } 18\end{array}$ & - & Fig. 8.2 \\
\hline 6 & $\begin{array}{l}\mathrm{Pb} .2000 / 696 \\
\mathrm{~Pb} .2000 / 697 \\
\end{array}$ & Tympanotonos margaritaceus & $\begin{array}{l}\text { trench } \alpha, \text { square } 22 \\
\text { trench } \alpha, \text { square } 22\end{array}$ & - & Fig. 8.3 \\
\hline 7 & not inv. & $\begin{array}{l}\text { Tympanotonos margaritaceus } \\
\text { ( } 2 \text { pieces) }\end{array}$ & trench $\gamma$, square 15 & - & Fig. 8.4 \\
\hline 8 & $\begin{array}{l}\mathrm{Pb} .2002 / 21 \\
\mathrm{~Pb} .2002 / 094 \\
\end{array}$ & $\begin{array}{l}\text { burrow infill (2 pieces) } \\
\text { (possible refit) }\end{array}$ & $\begin{array}{l}\text { trench } \beta \text {, square } 5 \\
\text { trench } \gamma, \text { square } 5 \\
\end{array}$ & $\begin{array}{l}- \\
270 \mathrm{~cm} \\
\end{array}$ & Fig. 13.1 \\
\hline 9 & $\begin{array}{l}\mathrm{Pb} .2000 / 721 \\
\mathrm{~Pb} .2000 / 794\end{array}$ & $\begin{array}{l}\text { Trochosmilia sp. } \\
\text { (possible refit) }\end{array}$ & $\begin{array}{l}\text { trench } \alpha, \text { square } 29 \\
\text { trench } \alpha, \text { square } 29\end{array}$ & - & Fig. 13.4 \\
\hline
\end{tabular}

Artefacts of phyllite were reported earlier from the Epigravettian site Pilismarót-Bitóc in the Danube Bend (under the name of serpentinite). ${ }^{7}$ From the Mogyorósbánya locality 38 phyllite objects are known; 31 of them were excavated in settlement spot III. The spatial distribution of the 28 piece plotted artefacts is shown on Fig. 1.2.

\section{PHYLLITE ARTEFACTS}

The majority of the pieces are very small, platy fragments following the foliate structure of the rock. During the analysis four larger artefacts were reconstructed. A typical flake was found in the eastern part of settlement spot III, five fragments of a not modified pebble and a sixth piece, lying at a distance of 1.5 meter was documented in the northernmost part of the excavated surface.

A manufactured and incised pebble (Fig. 2) ${ }^{8}$ was refitted from two fragments. The lateral parts of this piece were scraped (the pattern of 'trace de brutage' is clearly observed) and a short flake was removed from one of the edges. Along the opposite side of the pebble eight more or less parallel running, rhythmical and in two cases reasserted incisions were performed. The faces of the pebble are covered by cortex and one of them was modified by deep, sub-parallel grooves at both ends of the piece. The marks on the thicker ('distal') part of the artefact suggest that it might have been fragmented during manufacture.

Sandstone and limestone pebbles with incised pattern, slightly smaller than the Mogyorósbánya piece were found on the Epigravettian site of Pilismarót-Pálrét ${ }^{9}$ in the Danube Bend. The carefully shaped limestone disc from the Early Gravettian locality of Bodrogkeresztúr-Henye ${ }^{10}$ (Tokaj Mountains, North-eastern Hungary) on the other hand was manufactured by powerful notches.

Artefacts of phyllite, marl and limestone with incisions around the perimeter and cutmarks on their surfaces were published from the Gravettian grave Brno $\mathrm{II}^{11}$ and from the settlement of Pavlov I in Moravia, ${ }^{12}$ as well as from the earliest Gravettian assemblage of Mitoc in the Prut valley, ${ }^{13}$ and the young Gravettian horizon of Poiana Cireşului in the Bistriţa valley (both in Romania). ${ }^{14}$ These pieces clearly differ from the Mogyorósbánya object by their small

\footnotetext{
${ }^{7}$ Dobosi 2006, 41

${ }^{8}$ Its length is $56 \mathrm{~mm}$, the width is $60.5 \mathrm{~mm}$ and the thickness is $22.5 \mathrm{~mm}$.

${ }^{9}$ Dobosi et al. 1983, 290, Fig. 5,6a-c.

${ }^{10}$ VÉRTES 1965; Dobosi 2000, 50-54.
}

\footnotetext{
${ }^{11}$ Makowski 1892; Oliva 2000.

${ }^{12}$ Svoboda-Frouz 2011, Fig. $7 \mathrm{~b}$.

${ }^{13}$ Beldiman-SzTancs 2008, 69.

${ }^{14}$ CÂrciumaru et al. 2018, 236.
} 


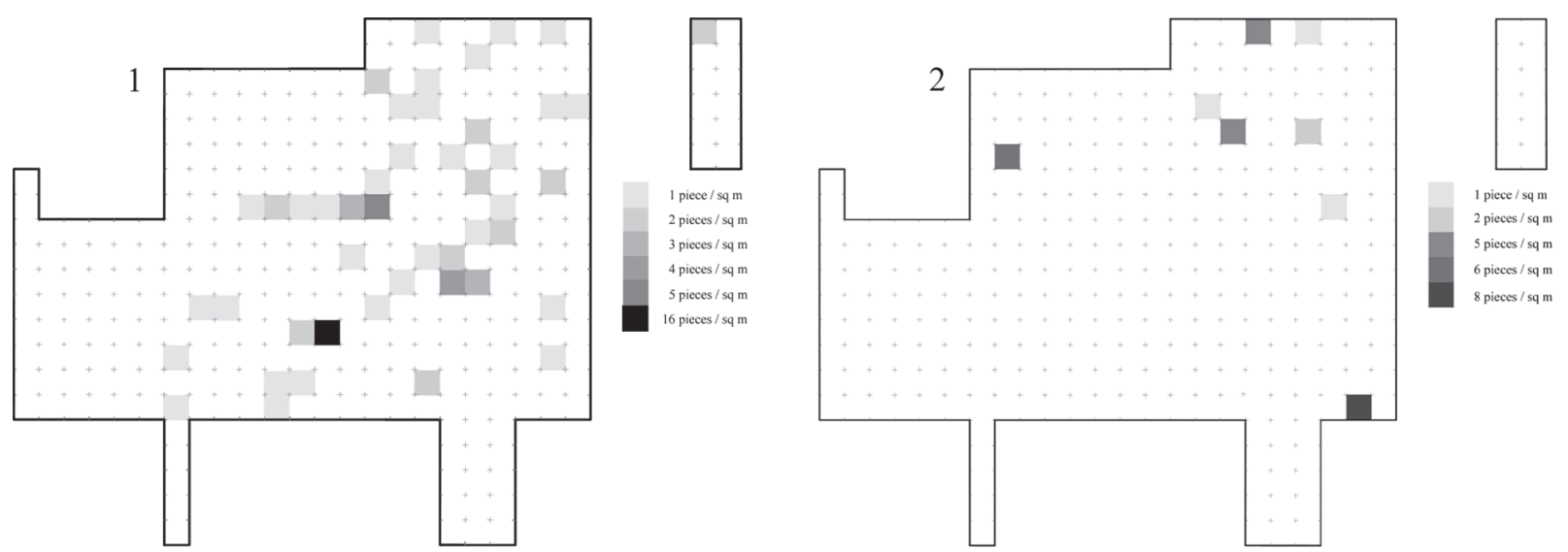

Fig. 1. Mogyorósbánya III. 1: Spatial distribution of the Palaeogene and Neogene fossils; 2: phyllite artefacts. Grid: $1 \mathrm{~m}$
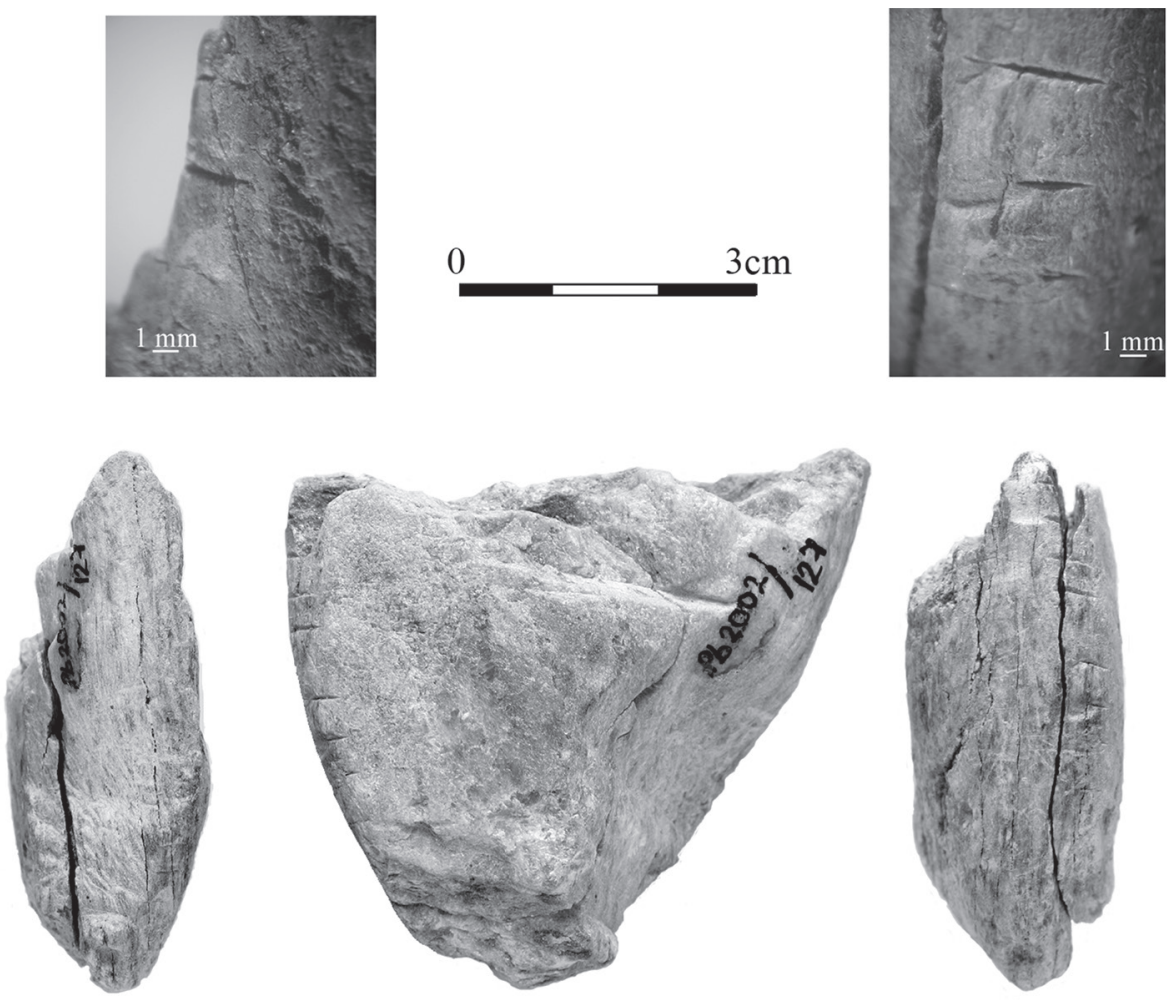

Fig. 2. Mogyorósbánya III. Manufactured and incised pebble (drawing: Katalin Nagy, photograph: Judit Kardos, HNM)

dimensions and the presence of perforation. ${ }^{15}$ The incised quartzite pebble with traces of red ochre from this later assemblage ${ }^{16}$ and the triangular artefact of sandstone with six incisions from Předmosti ${ }^{17}$ are seemingly similar to the Mogyorósbánya artefact; however, these items are interpreted as hammerstones or rubbing stones.

The morphology of the last phyllite artefact, a piece with sharp edge is similar to the polished axes (Fig. 3). Together with seven fragments of the same item it was found in the south-eastern part of settlement spot III. The non-fragmented parts of the piece are covered by flat, manufactured surfaces, with the exception of the convex left

${ }^{15}$ Moreover, in these assemblages incisions are also observed
on a number of 'rondels' and other objects of haematite, bone, ivory and
mammoth molar: e.g. MAKOWSKI 1892; CÂRCIUMARU et al. 2018 .

Acta Archaeologica Academiae Scientiarum Hungaricae 69, 2018
${ }^{16}$ CÂRCIUMARU et al. 2004, 123; CÂRCIUMaru et al. 2018, 235.
${ }^{17}$ ABSOLON-KLÍMa 1977, 211, Taf. 199, 3471. 

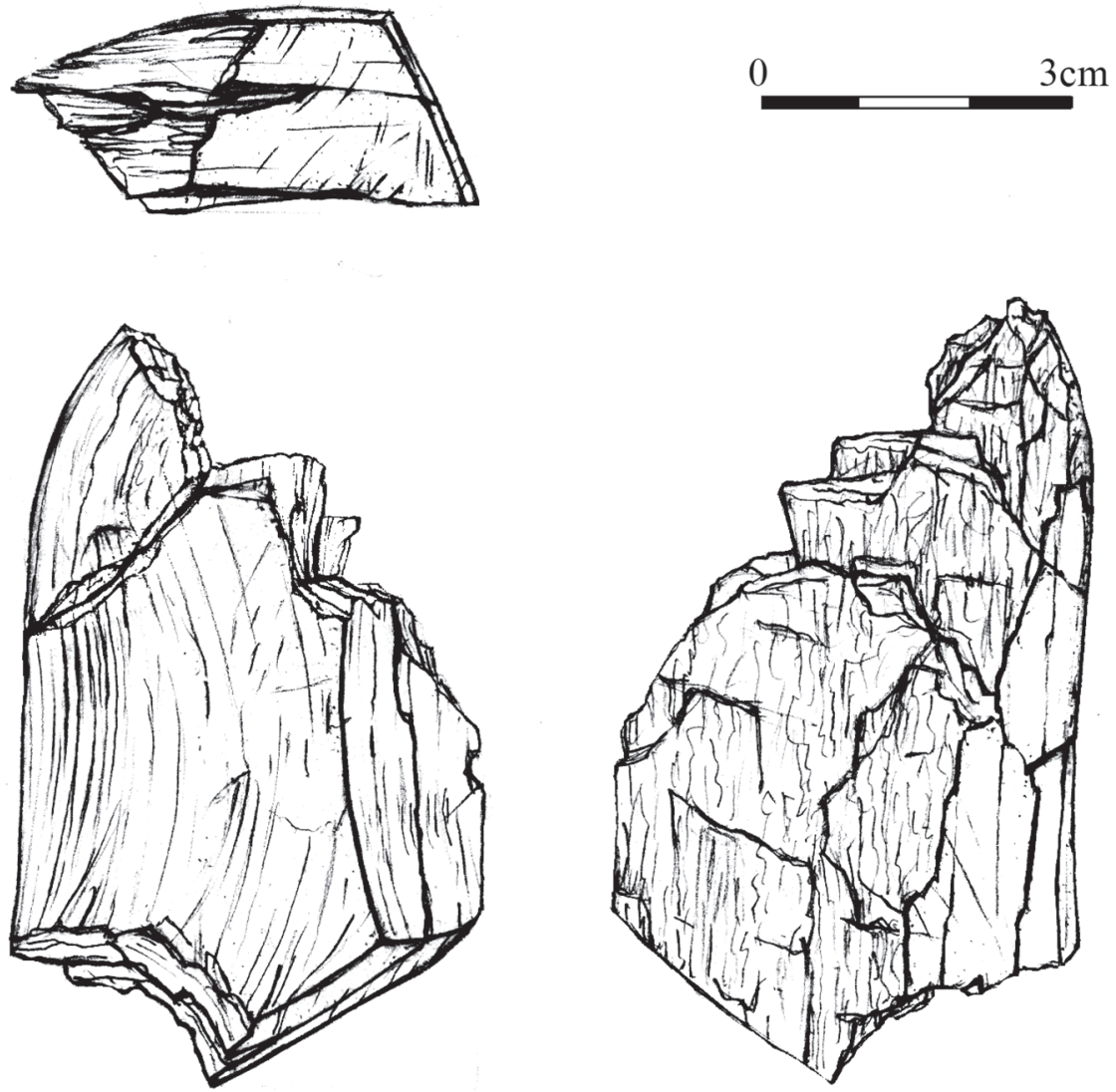

Fig. 3. Mogyorósbánya III. Artefact with sharp edge of phyllite (drawing: Katalin Nagy)

side, shaped also by scraping. On the large part of the other (flat or 'ventral') face the natural cleavage surface of the pebble is visible. Unfortunately, the heavy fragmentation prevents the reconstruction of the original shape of this object, even if two amorphous pieces were conjoined to the largest fragment. ${ }^{18}$ Importantly, during the first trial excavations of spot III a little fragment of a similar artefact was found with manufactured surface, however, the exact place of the recovery was not documented.

The morphology of the piece with sharp edge is compared to the ochre artefacts of unknown function published, for instance, from Langmannersdorf. ${ }^{19}$ Possibly both ochre and phyllite were used during preparation of leather, however, the secondary carbonate layer, which covered the artefacts does not allow microscopic investigations of the Mogyorósbánya pieces.

\section{PALAEOGENE AND NEOGENE FOSSILS}

The biostratigraphic evaluation of the fossil remains shows that one quarter of the pieces were collected from the local Eocene (55-33.4 million years old) sediments. The large foraminifer Nummulites or the Diastoma and Ampullina gastropods are common elements of these formations in the Carpathian Basin. Moreover, the occurrence of several taxa including corals has been reported from the surface outcrops in the vicinity of the site ${ }^{20}$ and from the Dorog Basin. ${ }^{21}$ The little cone shell Conus parisiensis, on the other hand, is not known from the Gerecse region until now, although the Neszmély outcrop yielded small sized molluscs. ${ }^{22}$ The nearest sources of the Tympanotonos

\footnotetext{
${ }^{18}$ The dimensions of the reconstructed artefact are: length: $73.5 \mathrm{~mm}$, width: $45.5 \mathrm{~mm}$, thickness: $21.5 \mathrm{~mm}$.

${ }^{19}$ Angeli 1953. nr. 50088, Taf. XI,1.
}

\footnotetext{
${ }^{20}$ E.g. Kolosváry 1949; SzŐTs 1956, 99, 100.

${ }^{21}$ BARTHA-KECSKEMÉTINÉ KÖRMENDI 1963.

${ }^{22}$ Strausz 1974.

Acta Archaeologica Academiae Scientiarum Hungaricae 69, 2018
} 
hungaricus were reported from outcrops around Gánt lying at a distance of $43 \mathrm{~km}$ from Mogyorósbánya in southwestern direction, where this gastropod was very abundant. ${ }^{23}$ Finally, the coral Isis may have been collected from the sediments lying around Páty, Nagykovácsi and Budapest ${ }^{24}$ (30 km from Mogyorósbánya in southern direction).

The spatial data of 16 piece-plotted Eocene fossils from spot III (Fig. 4.1) show a rather even distribution with two reconstructed refit groups (nr. 1 and 9).

One third of the fossil specimens are dated to the Upper Oligocene (Egerian stage: 25.8-20.3 Ma). Tympanotonos margaritaceus is a common fossil of this period; the nearest occurrences of this species are known from several surface outcrops lying at a distance of at least $15 \mathrm{~km}$ in north-eastern (Kovačov, Malá nad Hronom), eastern (Kesztölc), southern and south-eastern (Tarján, Máriahalom) direction from the Mogyorósbánya site. ${ }^{25}$ At the same time, outcrops with Dentalium shells were mentioned from the region of Törökbálint, Pomáz, Diósjenő or Rétság, ${ }^{26}$ lying at a larger distance (31-46 km), and Aporrhais callosa was also described from the Upper Oligocene outcrops of Diósjenő. ${ }^{27}$

The spatial distribution of the 30 Oligocene specimens plotted in spot III (Fig. 4.2) show two clear concentrations in the eastern part and the middle of the trench. With two exceptions the six refit groups (nr. 2-7) document the on-site fragmentation of the gastropod shells.

One quarter of the fossils from Mogyorósbánya belong to the Pannonian stage (11.6-7.4 million year). The two Melanopsis species are missing from the faunas of the northern and eastern part of the Gerecse Mountains ${ }^{28}$ and in the classical sediments of the Tata outcrops. ${ }^{29}$ One of the possible sources of these species is suspected in the outcrops around Tinnye (17 km from the site in south-eastern direction) ${ }^{30}$ close to the Máriahalom sandpit. Moreover, similar fauna was also reported from the region around Kocs, ${ }^{31}$ lying at a distance of $30 \mathrm{~km}$ in western direction from Mogyorósbánya.

The distribution map of 24 Pannonian fossils plotted in spot III (Fig. 3.3) reflects a single artefact concentration in the southern part of the trench, clearly separated from the Oligocene scatters. Besides, only four pieces were documented in the middle and the northernmost part of the excavated territory.

Finally, in 18 cases the exact systematic, and therefore biostratigraphic determination of the fossils was not possible. The little fragments of thick bivalve shells, identified as oyster (Ostrea sp.) and the small gastropod Bittium are known both from the Late Oligocene ${ }^{32}$ and Eocene ${ }^{33}$ formations. Glycymeris is a common bivalve not only of this later period (the outdated term Pectunculus Sand refers the mass occurrence of glycymerids), but also in the Middle Miocene (Badenian stage: 16.3-12.8 million years ago) outcrops known in the south-western part of the Börzsöny Mountains. ${ }^{34}$

With the possible exceptions of this surface collected shell and the worm tubes Badenian fossils are absent from the Mogyorósbánya assemblages, which is surprising, as the Pebble Gravettian locality of Szob-Ipoly-part ${ }^{35}$ in the Danube Bend, yielding nearly 400 shells was specialised for collecting the fossil molluscs from this formation. Moreover, Middle Miocene trinkets were also excavated on the Epigravettian sites of Pilismarót-Pálrét ${ }^{36}$ and probably Pilismarót-Bitóc, both lying on the opposite site of the Danube river. Finally, at Vác-Kis Hermányi út a single Badenian Cerithium (Thericium) michelottii shell, associated with an antler point and some flakes were found (unpublished data). ${ }^{37}$

In the contemporaneous Esztergom-Gyurgyalag assemblage Middle Miocene and Oligocene gastropods (eleven specimens of two species) were identified ${ }^{38}$ and the single gastropod shell found in the 'Lower Diluvium'

${ }^{23}$ SzŐTs 1953, 47. - The absence of this species in the Gerecse region was emphasised as having a clear palaeogeographical importance: SzŐTS 1956, 152.

${ }^{24}$ KolOSVÁRY 1949, 186; SzŐTS 1956, 118

${ }^{25}$ SENEŠ 1958; BÁLDI 1973; JANSSEN 1984.

${ }^{26}$ BÁLDI 1973, 336.

${ }^{27}$ BÁLDI 1973, 267 - Recently, both Aporrhais callosa and Dentalium kickxii (under the name of Antalis kickxii Nyst, 1843) were recorded from the Esztergom Basin, too: KovÁCS-VICZIÁN 2016, 235, Plate I. Fig. 13

${ }^{28}$ MAgYAR et al. 2017.

${ }^{29}$ KorPÁS-Hódi 1983; MÜLLER et al. 2007.

${ }^{30}$ This locality is known after the more than one hundred years old and short note by LÖRENTHEY 1902.

Acta Archaeologica Academiae Scientiarum Hungaricae 69, 2018
${ }^{31}$ STRAuSZ 1951, 286-288

${ }^{32}$ Máriahalom: JANSSEN 1984, 127.

${ }^{33}$ Neszmély and Mogyorósbánya: Strausz 1974, 42; SzŐTs 1956, 100.

${ }^{34}$ Csepreghy-MeZnerics 1956; Dulai 1996.

${ }^{35}$ GÁBORI 1969; MARKó 2007; DULAi 2007.

${ }^{36}$ The assemblage is partly published by J. Szabó, see: Dobosi et al. 1983.

${ }^{37}$ The collected loess snails (including Vestia turgida) date the site to the same horizon as Esztergom and Pilismarót - kind communication by E. Krolopp (06. 10. 1999.). MAGYAR 1991a 

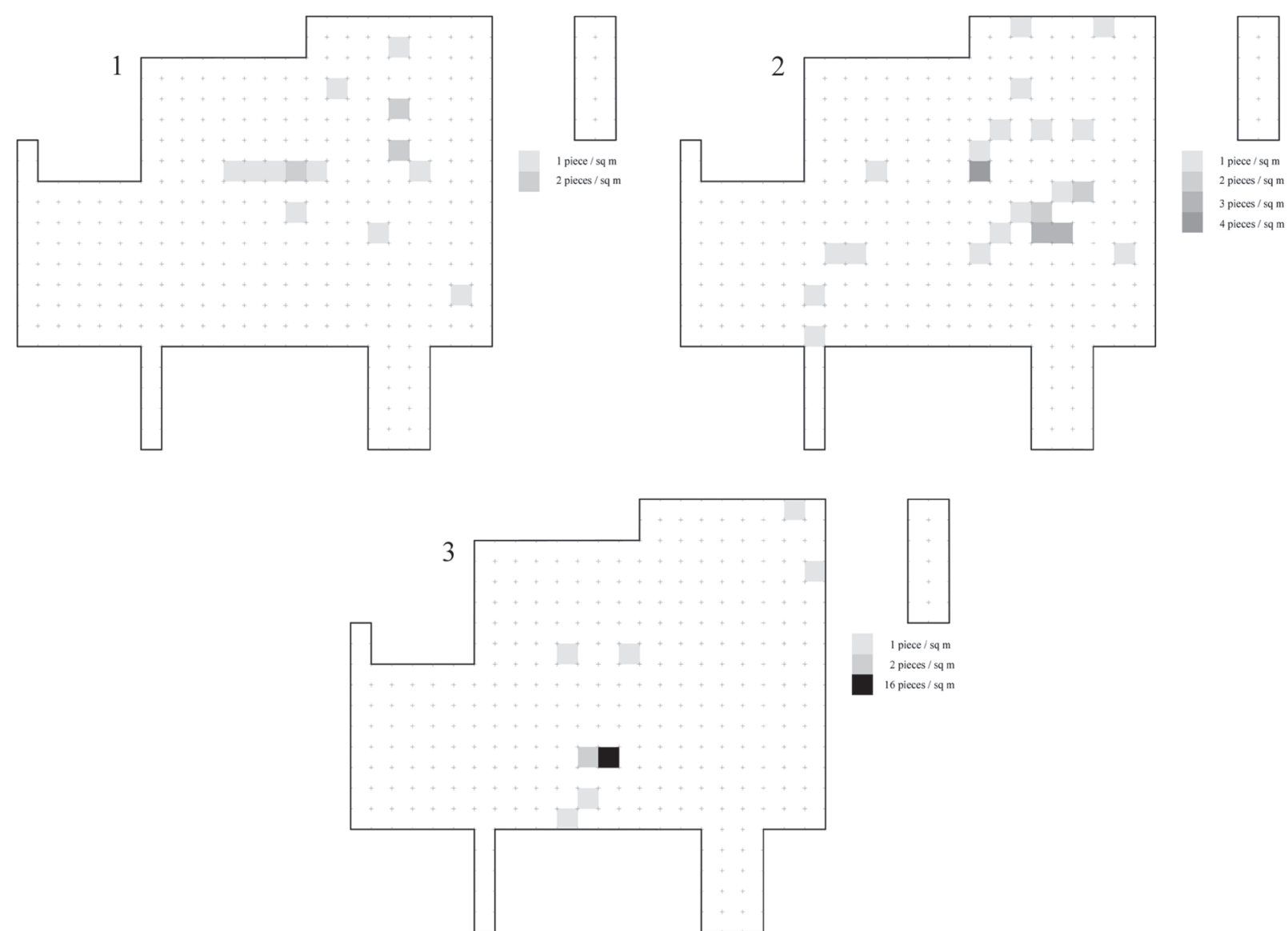

Fig. 4. Mogyorósbánya III. Spatial distribution of the Eocene (1), Oligocene (2) and (3) Pannonian fossils. Grid: $1 \mathrm{~m}$

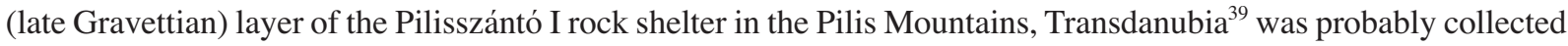
from Oligocene sediments, too.

The use of Pannonian melanopsids is known from the Epigravettian site of Jászfelsőszentgyörgy-Szúnyogos (in the northern periphery of the Great Hungarian Plain) ${ }^{40}$ from Verseg-Kertek alja (Cserhát region, Northern Hungary) and from the Čertova pec cave (near Radošina, Western Slovakia) ${ }^{41}$ tentatively placed to the earlier Upper Palaeolithic period and the Gravettian. At the same time, the biostratigraphic age of the fossil shells from the Bivak cave (Pilis Mountains), ${ }^{42}$ Ságvár (south of Lake Balaton) ${ }^{43}$ Csővár (Cserhát Mountains) ${ }^{44}$ and Tarcal (Tokaj Mountains in North-Eastern Hungary ${ }^{45}$ is not known precisely.

\section{THE HUMAN SELECTION}

Obviously, Palaeolithic humans followed different considerations than the taxonomic, biostratigraphic or palaeoecological approach used by present-day palaeontologist. As Eocene and Oligocene species of the Tympanotonos genus (T. calcaratus, T. hungaricus and T. margaritaceus) were found in the same find concentration in settlement spot III, a possible classification of the excavated fossils is based on apparent morphological features of the specimens.

${ }^{39}$ Kormos-Lambrecht 1915, 339.

${ }^{40}$ Dobosi 1993, 47.

${ }^{41}$ ProšEK 1950, 179, Obr. 119; BÁRTA 1965, 122, Tab. XXV; BÁRTA 1965 1972, 79, Obr 3.

\footnotetext{
42 JÁNOSSY et al. 1957.

${ }^{43}$ With the exception of a possible Pannonian bivalve, see infra.

${ }^{44}$ PATAY 1932.

${ }^{45}$ Dobosi 1974.
}

Acta Archaeologica Academiae Scientiarum Hungaricae 69, 2018 
Earlier, Y. Taborin ${ }^{46}$ distinguished seven groups among the perforated and suspended gastropods known from the Palaeolithic sites in France. However, the species Ancilla glandiformis was listed both among the ovoiide and fusiforme fossils, ${ }^{47}$ while Turritella and Tympanotonos shells known from the Mogyorósbánya collection were identified as en forme de cône allongée.

Based on the fossil mollusc assemblages from the Pavlovian sites in Moravia, Š. Hladilová described four morphological groups: smooth ovoid shells (like Conus, Melanopsis and Ancilla), tower-like shaped shells (Turritella), tubular remains (Dentalium and Serpula) and radial sculptures (basically bivalves) ${ }^{48}$ noting that the surface of ovoid shells are generally smooth, while tower-shaped fossils are often 'sculptured'. ${ }^{49}$

The most obvious groups of the intuitive classification of the Mogyorósbánya pieces (Table 3) are the tubular fossils (scaphopods and worm tubes), the gastropods with rich ornamentation as nodes and ribs on the shells (typically, Tympanotonos) and the simple gastropod shells with smooth surface (e.g. the melanopsids). Bivalves (or pieces with radial sculptures) are represented by a single surface-collected Glycymeris and some strongly fragmented Ostrea shells, found during the cleaning of the easternmost and the middle part of spot III. Bivalves generally played a subordinate role in the Palaeolithic assemblages in Hungary, even if the oldest fossils known from archaeological context in Hungary are the Glycymeris obovata shell, mentioned from the Late Middle or Early Upper Palaeolithic leaf-point assemblage of the Remete Upper cave ${ }^{50}$ and a Cardium from Verseg. ${ }^{51}$ From SágvárLyukas-domb, sorted into the same Pebble Gravettian industry as the Mogyorósbánya assemblage the presence of an Arca diluvii was reported. ${ }^{52}$ Another bivalve shell ${ }^{53}$ (possibly Prosodacnomya sp. from the Pannonian sediments of Tab and Kötcse lying close to Ságvár ${ }^{54}$ ) was catalogued in the Palaeolithic collection of the National Museum 25 years after the end of the last excavations of this site. Regrettably, the find circumstances of this fossil, not mentioned in the field notes and the preliminary reports by M. Gábori are not known.

Table 3.

Morphological groups of the fossil artefacts from the Pebble Gravettian Epigravettian and from not dated archaeological sites in Hungary (without Pleistocene species and fragmented pieces)

\begin{tabular}{|c|c|c|c|c|c|c|}
\hline & bivalve & ornamented gastropod & simple gastropod & tubular fossil & 'other fossil' & total \\
\hline Mogyorósbánya I & & 1 & 1 & & 1 & 3 \\
\hline Mogyorósbánya II & & 2 & & 1 & & 3 \\
\hline Mogyorósbánya III & 4 & 34 & 31 & 12 & 11 & 90 \\
\hline surface & 1 & 2 & & 1 & & 4 \\
\hline total & 5 & 39 & 30 & 14 & 12 & 100 \\
\hline Szob & 31 & 321 & 40 & 5 & & 397 \\
\hline Ságvár & 1 & & & 4 & & 5 \\
\hline Esztergom & & 17 & 5 & 73 & & 91 \\
\hline Pilismarót-Pálrét & & 2 & & 9 & & 11 \\
\hline Pilismarót-Bitóc, Lower layer & 2 & 3 & 1 & & & 6 \\
\hline Pilismarót-Bitóc, Upper layer & & & & 4 & & 4 \\
\hline Vác-Kishermányi út & & 1 & & & & 1 \\
\hline Bivak cave & 1 & & & & & 1 \\
\hline Jászfelsőszentgyörgy & & & 1 & & & 1 \\
\hline Tarcal & & & & 2 & & 2 \\
\hline Verseg-Kertekalja & 1 & 3 & 1 & 1 & & 6 \\
\hline Csővár-Csővár cave & & 3 & & & & 3 \\
\hline
\end{tabular}

46 TABORIN 1993, 265.

${ }^{47}$ TABORIN 1993, 266, 268 - Melanopsids were sorted into the latter group.

${ }^{48}$ Hladilová 2005, 382.

${ }^{49}$ HLadilová 2005, 383.

${ }^{50}$ GÁBORI-CsÁnK 1993, 267-269. - Today this shell is missing from the collection of the Budapest History Museum.

${ }^{51}$ Magyar 1990a.
${ }^{52}$ According to M. Gábori and V. Gábori this shell was excavated at an unknown place of the site (GÁBORI-GÁBORI 1957, 13), while the inventory book of the National Museum indicates that it was found by S. Gallus after 1935. In fact, the first photo of the artefact was published in a report on the 1930 excavation (LACZKó et al. 1930, 220, 304, Taf. 140).

${ }^{53}$ Dobosi 1985, 26, Fig. 3,6.

${ }^{54}$ MÜLler-Magyar 1992. 
On the third Pebble Gravettian site, Szob-Ipoly part $8 \%$ of the important mollusc assemblage was bivalves. ${ }^{55}$ Finally, in the unpublished lower layer of the Epigravettian site of Pilismarót-Bitóc two bittersweet (Glycymeris) shells, and in the contemporaneous layer of the Bivak cave a fragment of an Arca or Glycymeris was found. ${ }^{56}$

\section{Tubular fossils}

In the Mogyorósbánya collection 14 Dentalium and Vermetus shells, as well as worm tube fragments are identified, each showing traces of human manipulation. The Dentalium and Vermetus shells were sliced and the three worm tube fragments with a uniform diameter and similar length data suggest for the on-site cutting of a single fossil, even if the fragments are not conjoined. On the other hand, the eroded longitudinal ribs and the notches on the rounded extremities indicate the traces of intense use of the pieces (Fig. 5). Accordingly, the majority of the Dentalium fragments are 7-11 mm long (Fig. 6.1). Two tusk shells and the single Vermetus remain form another closed group (with a length of 25-27.5 mm), however, one must take into consideration that the Dentalium specimens were excavated both in settlement spot II and III (Fig. 5.9, 10) and the Vermetus (Fig. 5.11) was collected on the surface as a stray find.

The spatial data of the pieces found in spot III show a relatively even distribution in the eastern part of the excavated trench (Fig. 6.2), with a single concentration of three worm tube fragments. At the same time, the longest Dentalium (refitted from two fragments: Fig. 5.12) was collected in the south-eastern part of spot III.

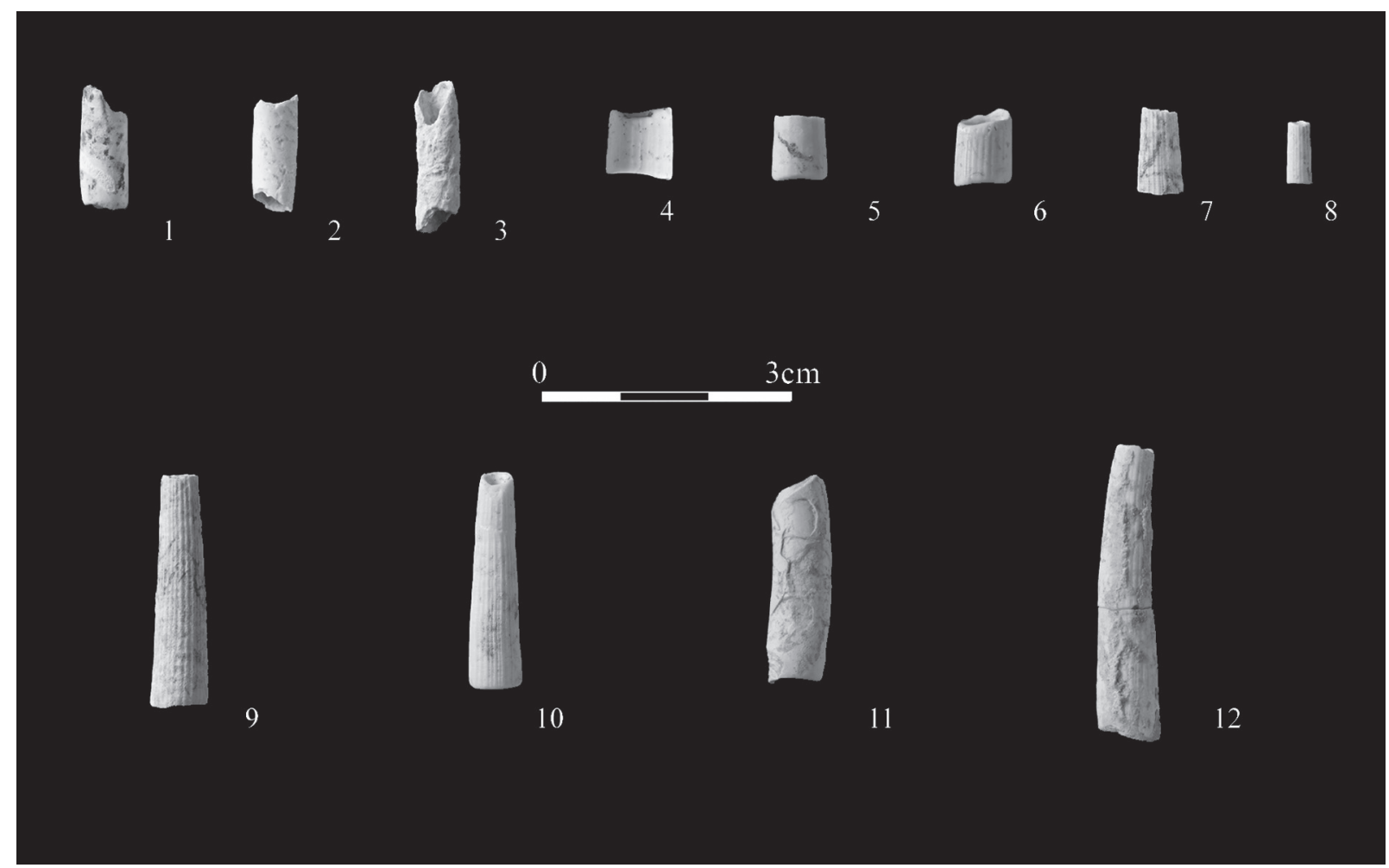

Fig. 5. Mogyorósbánya. Tubular fossils from the excavations (worm tube: 1-3; Dentalium: 4-9, 12; Vermetus: 11) from settlement spot II (9) and III $(1-8,12)$ and from the surface $(11)$

${ }^{55}$ DULAI 2007 - In the assemblage collected at the nearby geological outcrop on the traditional way (without wet-sieving) and stored in the Natural History Museum bivalves are important elements, represented by 23\%: DULAI 1996, 44.
${ }^{56}$ JÁNOSSY et al. 1957, 31, Taf. I, 2. - A recently obtained radiocarbon date (Gd-15614: 15.970 207 B.P., see PAZONYI 2006, 81) places the upper yellow layer of this cave to the Epigravettian period.

Acta Archaeologica Academiae Scientiarum Hungaricae 69, 2018 
1

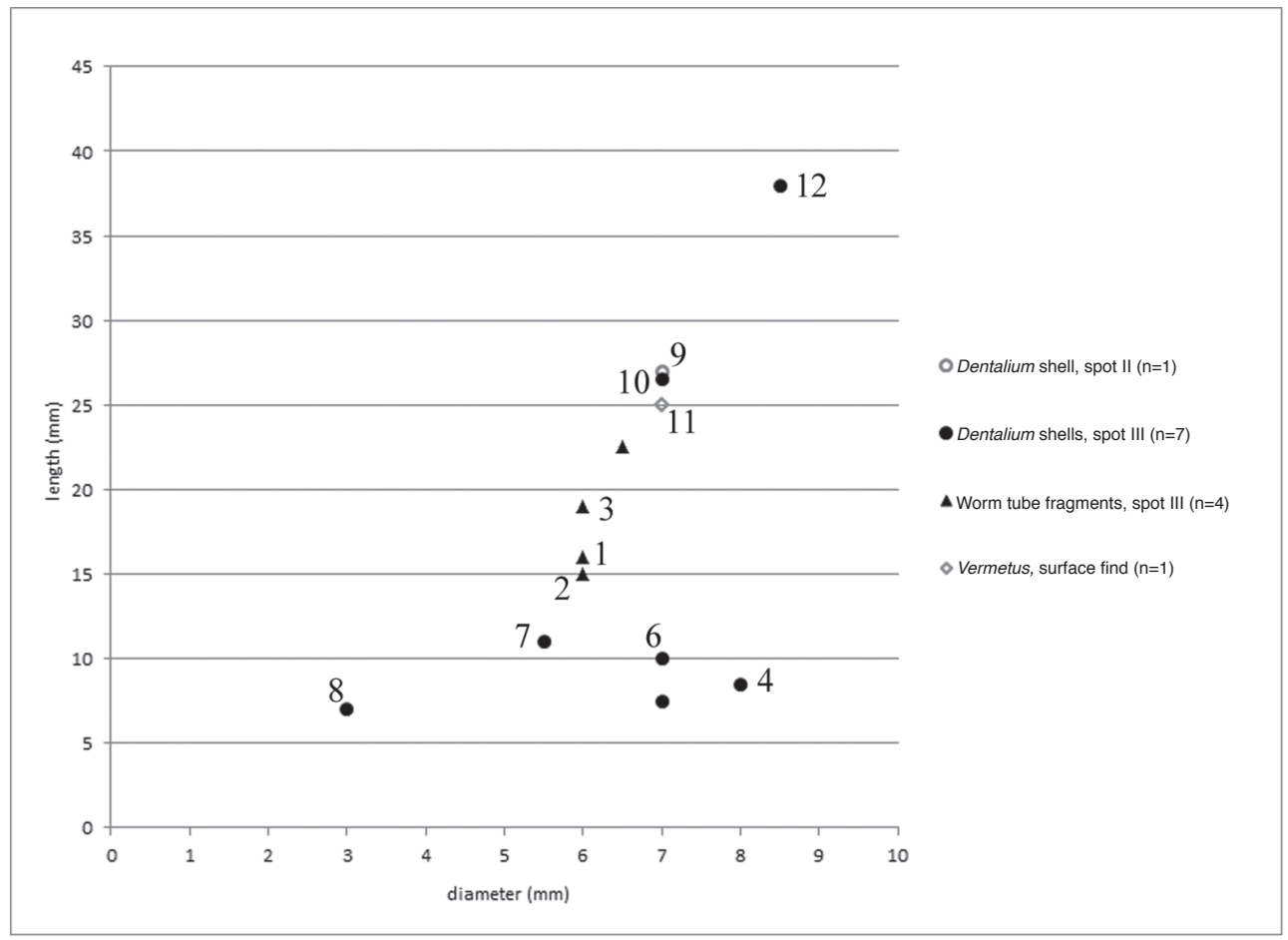

2

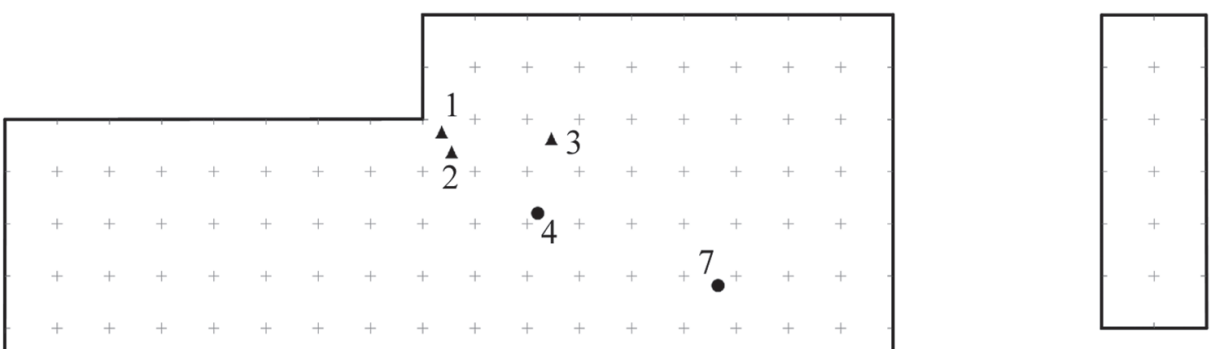

- Dentalium shell

$\Delta \quad$ worm tube fragment

12

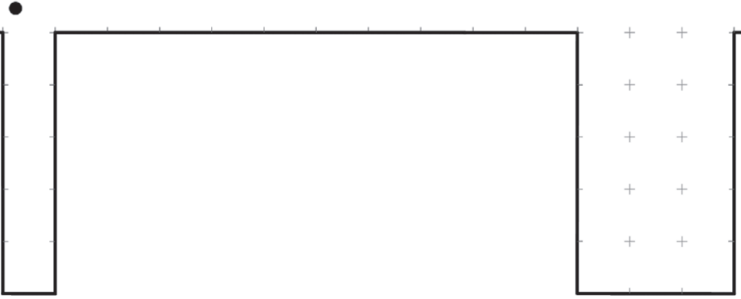

Fig. 6. Mogyorósbánya. Metrical data (a) and spatial distribution of the tubular fossils in settlement spot III (b). For the legend see Fig. 5 Acta Archaeologica Academiae Scientiarum Hungaricae 69, 2018 
The Dentalium remains from Szob are longer than the Mogyorósbánya specimens (Fig. 7.1), partly because the Badenian tusk shells are larger than the Oligocene pieces ${ }^{57}$ partly as only one manufactured Dentalium shell is found today in the collections from this site..$^{58}$

From Ságvár a single Dentalium bead, found before the Second World War was published. ${ }^{59}$ The report on the 1957 excavations mentioned four pieces with a length of 1 to $3 \mathrm{~cm}$ from the upper culture layer. ${ }^{60}$ The shells published later on a photograph ${ }^{61}$ are longer than these data, which may raise further questions about the find circumstances of the pieces and points to the problems at the analysis of the assemblage of this important site. ${ }^{62}$

In the Epigravettian assemblage of Esztergom-Gyurgyalag and Pilismarót-Pálrét, ${ }^{63}$ as well as the stratigraphically younger upper layer of Pilismarót-Bitóc (unpublished data) tusk shells were the most popular fossil trinkets and on the Tarcal site only tubular fossils: a Dentalium and a Vermetus remains were excavated ${ }^{64}$ From metrical point of view, these artefacts are clearly longer than the manufactured pieces from Mogyorósbánya (Fig. 7.2), which reflect the preference for short beads on this later site.

On the Palaeolithic localities of Lower Austria, scaphopods constitute the most numerous group of fossils at Grubgraben ${ }^{65}$ and exclusively Dentalium shells were found at Langmannersdorf ${ }^{66}$ both dated roughly to the same period as the Mogyorósbánya locality. Several hundreds of Dentalium and some Serpula shells were found in the Late Gravettian site of Moravány-Podkovica (Váh valley, Western Slovakia) ${ }^{67}$ and Dentalium specimens were also reported from the surface collected assemblage of the same period from the nearby Hubina I locality. ${ }^{68}$

As a total, the Mogyorósbánya and Szob assemblages, characterised by the moderate number of tubular fossils clearly differ from the Epigravettian pattern, and that one, known from Western Slovakia and Lower Austria, all dominated by scaphopods. On the other hand, In Romania a single Dentalium bead was excavated until now, in the Gravettian layer I at Poiana Cireşului; ${ }^{69}$ the metrical data of this piece are even smaller than the Mogyorósbánya species.

\section{Ornamented gastropods}

The species of Tympanotonos, Turritella and the little shells of Diastoma and Bittium are identified as ornamented gastropods in this paper. The spatial distribution of 31 piece-plotted shells (Fig. 8.1) shows two concentrations. In the middle of spot III different Tympanotonos species from different geological formations were documented, while in the south-eastern part several of on-site fragmented the pieces (Table 2, Fig. 9.1-3) were found. The interpretation of refit groups 4-6 is rather problematic, ${ }^{70}$ especially, as in the Máriahalom sandpit gastropod fragments, very similar to the Mogyorósbánya pieces were documented ${ }^{71}$ suggesting that the given pattern of the fragmentation does not necessarily indicate human impact. The minimal dislocation of the elements of each refit group shows that probably sediment pressure or trampling caused the fragmentation.

${ }^{57}$ BÁLDI 1973, 336.

${ }^{58}$ According to the field notes of A. J. Horváth in 1937 ten Dentalium beads were excavated in the lower layer of this site (DoBOSI-VÁRI 1997, 70). These artefacts are, however, missing from the collections today.

${ }^{59}$ GÁBORI-GÁBORI 1957, 13.

${ }^{60}$ GÁBORI-GÁBORI 1958, 22; GÁBORI 1959, 5, 12. - In fact, in the short type-written description from this season (stored under the number 203.S.III. in the Archives of the Hungarian National Museum) only three Dentalium beads were mentioned.

${ }^{61}$ GÁBORI 1964, 40, T. VIII.

${ }^{62}$ These artefacts and the Prosodacnomya shell were got into the Palaeolithic Collection of the National Museum after closing of the prehistoric exhibition of the Veszprém Museum in 1974.

${ }^{63}$ Magyar 1991a; SzABó 1983.

${ }^{64}$ Dobosi 1974, 12

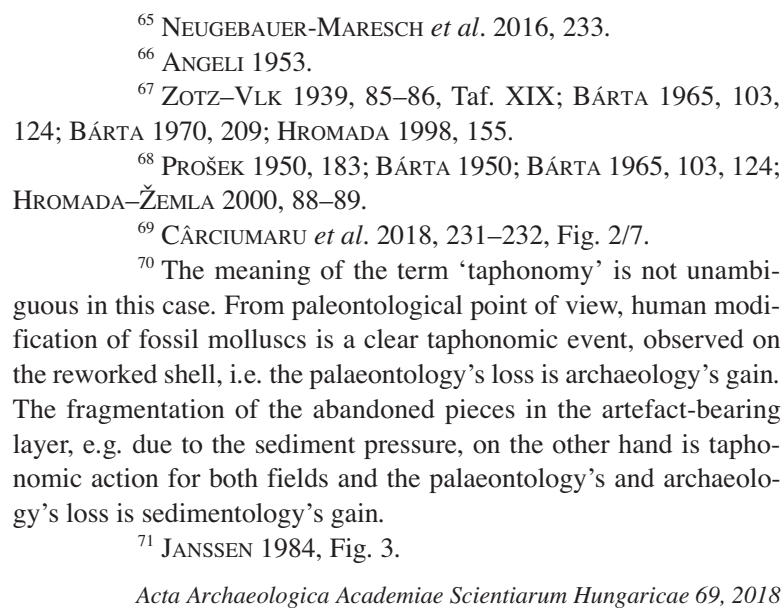



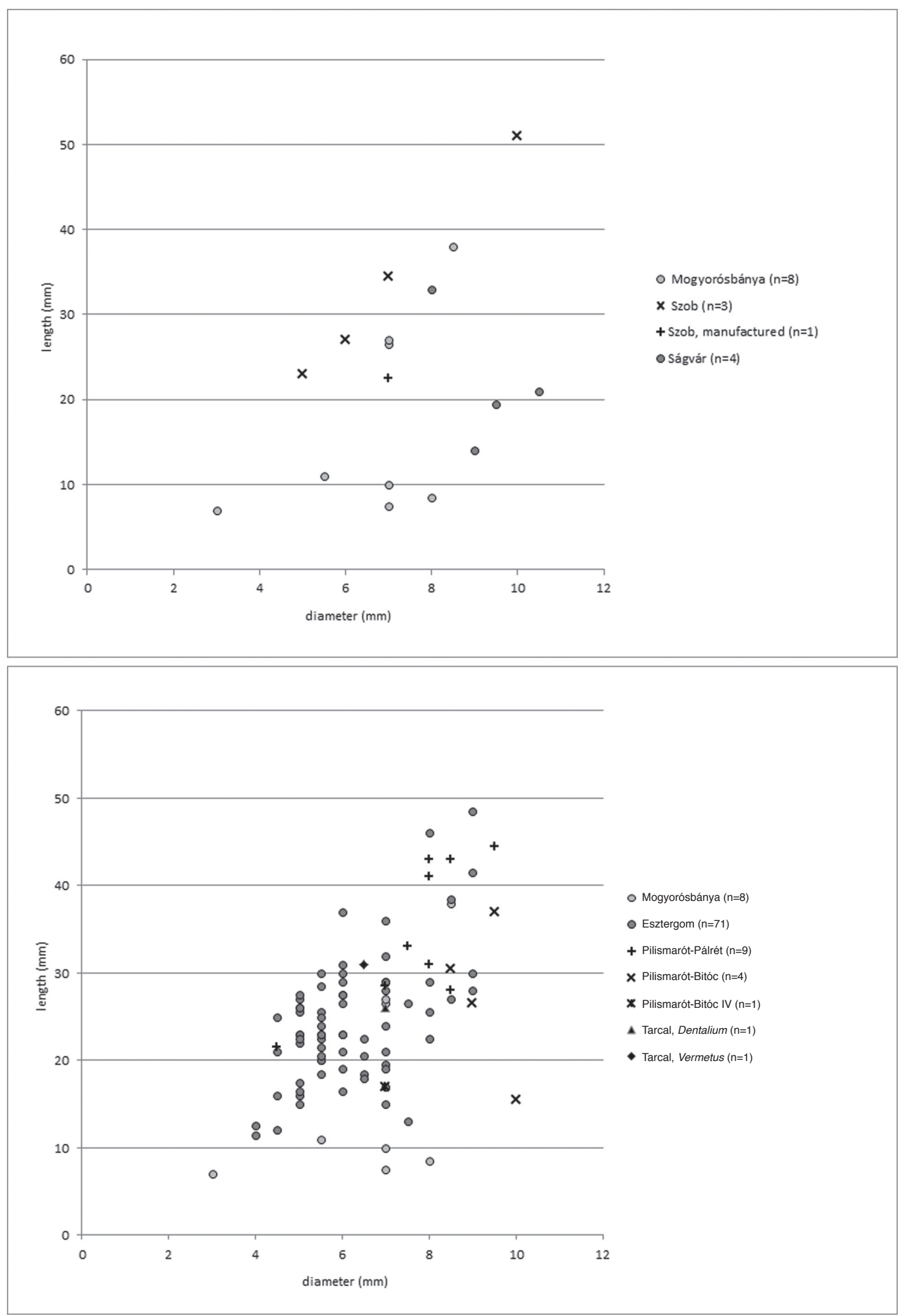

Fig. 7. Mogyorósbánya. Metrical data of Dentalium specimens compared to pieces from the Pebble Gravettian (1) and Epigravettian (2) assemblages 


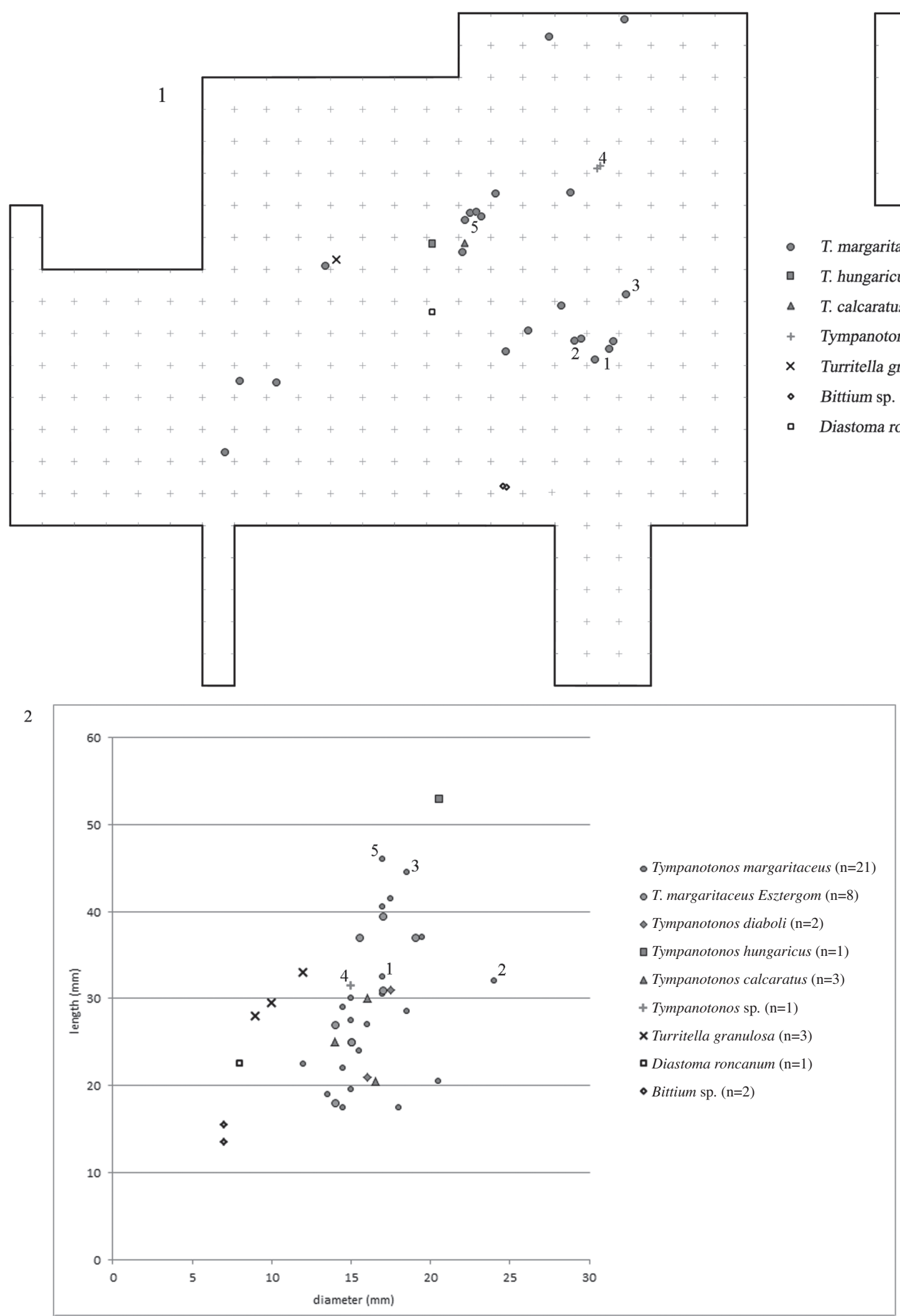

Fig. 8. Mogyorósbánya. Spatial distribution (1) and metrical data (2) of the ornamented gastropods. For the legend see Fig. 9 


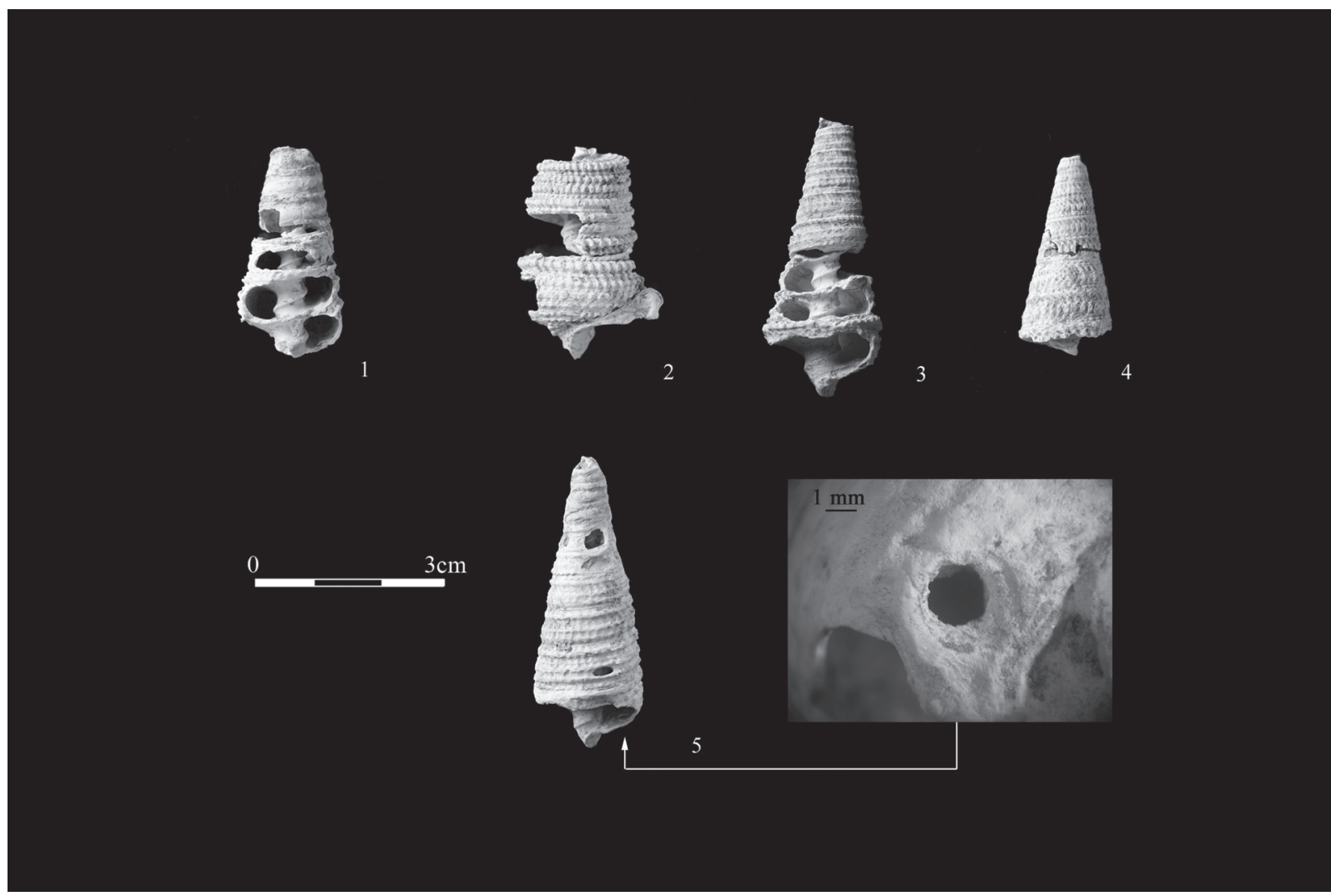

Fig. 9. Mogyorósbánya III. Ornamented Tympanotonos shells. Refit groups 4-7 (1-4) and manufactured piece (5)

Only the largest Tympanotonos margaritaceus shell, found in the first concentration shows traces of human manipulation (drilling with rotational movement), carried out on the last whorl of the shell (Fig. 9.5). ${ }^{72}$ The apical part of the same specimen is intensively worn in as much, that the natural ornamentation and the thick wall of the shell was completely eroded. Possibly these localised traces document the use of this unique piece. Unfortunately, the heavily fragmented and sometimes eroded shells do not let to draw any further conclusions.

On the Epigravettian site of Esztergom-Gyurgyalag, dominated by tubular fossils some ornamented gastropod shells were also excavated. The metrical data measured on the T. margaritaceus and T. hungaricus specimens from Mogyorósbánya and Esztergom-Gyurgyalag (Fig. 8.2) fit to the range of the fossils of the Máriahalom and Gánt outcrops; the length of the shells did not reach the maximal dimensions of these species ${ }^{73}$ as it was suggested in the case of the Glycymeris found in the Remete Upper cave. ${ }^{74}$

Turritella is represented by four fragments of three specimens in the Mogyorósbánya assemblages; the piece excavated in spot III (refit group 3) and the small Diastoma and Bittium remains were found relatively far from the large ornamented shells.

Turritella species are the dominant elements of the Szob collection, representing $83.65 \%$ of gastropods and $78.39 \%$ of the fossil remains in general. ${ }^{75}$ In the lower layer of Pilismarót-Bitóc three turritellids were found, and a number of specimens were collected during the surface prospections in the vicinity of this site. Bearing in

${ }^{72}$ Borings of the predatory naticid and muricid molluscs, showing circular pattern were documented on $0.9 \%$ and $1 \%$ of the gastropod shells collected in the Máriahalom sandpit: OLLÉ 1996, 15-16. - The conical cross-section of the hole observed on the Mogyorósbánya specimen is similar to the borings by the former group of predatory gastropods (D'ERrICO et al. 1996, 246-248, Fig. 4A, 5A). However, the observed asymmetric cross-section of the oval perforation, the presence of striations along its periphery and the absence evidences of chemical alteration caused by the acids secrated by the naticids, suggest for a human manipulation (D'ERRICO et al. 1996, 250, Fig 7).

${ }^{73}$ The maximal length of the shells from these outcrops is 6 cm: JANSSEN 1984, 126; SzÕTS 1953, 47.

\footnotetext{
${ }^{74}$ GÁBORI-CsÁNK 1993, 267-269.

${ }^{75}$ Dulai 2007.
} 
mind the Turritella shell found in the Gravettian layer of the Pilisszántó I rock shelter ${ }^{76}$ the importance of this ornamented gastropod during the Late Upper Palaeolithic is evident.

\section{Simple gastropods}

The 26 melanopsids together with the single shells of Conus, Ancilla and Aporrhais ${ }^{77}$ are referred as 'simple gastropods'. Their spatial distribution with a very pronounced concentration of $17 \mathrm{M}$. impressa shells, seemingly elements of a single 'rope' or 'necklace' is presented on Fig. 10. Moreover, in the vicinity of this feature three large melanopsids (M. fossilis) and a worn snail shell (Gastropoda indet.) were documented in a relatively closed scatter.

At Szob numerous fossil molluscs, collected by in the immediate vicinity of the site and several heaps of shells were excavated in 1939, 1940 and 1964 by A. Horváth, M. Mottl and M. Gábori. ${ }^{78}$ No spatial information is available about the melanopsids, including numerous fragmented pieces found in a cryoturbated layer in the Čertova pec cave ${ }^{79}$ and about the elements of the reconstructed necklace of Dentalium beads from Moravány-Podkovica. ${ }^{80}$ On the other hand, the 13 fossil shells (cca. 14\% of the trinkets) excavated in a single square meter at EsztergomGyurgyalag $^{81}$ and the Dentalium beads found in the first Palaeolithic dwelling structure at Ságvár implied a kind of rope, similar to the Mogyorósbánya observations. Finally, a complete necklace with 10 perforated Homalopoma sanguineum and 38 Lithoglyphus naticoides shells were reported from the 26 ka old Gravettian III layer at Poiana Cireşului. ${ }^{82}$

In the case of the supposed necklace from Mogyorósbánya only three specimens show traces of human modification. One of them (Fig. 11.1) was clearly perforated, ${ }^{83}$ on another shell the trace of not finished sawing is documented (Fig. 11.3) ${ }^{84} \mathrm{~A}$ large hole (with the dimensions of $7.5 \times 5 \mathrm{~mm}$ ) possibly of natural origin ${ }^{85}$ on the apical third of a shell could have been utilised by humans (Fig. 11.2). One of the melanopsids found relatively far from the concentration, among ornamented Tympanotonos shells was broken during the perforation or preparation by scraping, performed close to the aperture (Fig. 11.4). ${ }^{86}$ Finally, on some pieces (including two elements of the 'necklace') the rather irregular holes may also be regarded as human manipulations. However, their location (close to the apex of the shell) and their small dimensions $(0.7 \times 1.5 \mathrm{~mm})$ question the validity of this interpretation.

The single Aporrhais and Ancilla remains (Fig. 11.5-6) excavated at a distance of $65 \mathrm{~cm}$ from each other, in the Tympanotonos margaritaceus concentration were manufactured on the back of the shell, opposite to the aperture. ${ }^{87}$ In this later case, the upper margin of the hole is most probably a regenerated natural injury while the lower one is of human origin. Importantly, the metrical data of these two specimens are very close to the Melanopsis shells showing unfinished sawing and scraping (Fig. 11.3,4; Fig. 12).

Similar pattern of manufacture was identified on a Tympanotonos shell from Esztergom-Gyurgyalag and on the large Conus shell in the unpublished material from the lower layer of Pilismarót-Bitóc. Moreover, in the available literature several pieces with traces of sawing were reported, i.e. from the Late Gravettian assemblage from Mainz-Linsenberg, ${ }^{88}$ from the Čertova pec cave ${ }^{89}$ and on the Conus ventricosus and Cypraea sanguinolenta specimens from Moravány-Žakovska (Váh valley, Slovakia). ${ }^{90}$

${ }^{76}$ Kormos-LAmbrecht 1915, 339, Fig. 15.

${ }^{77}$ In fact, the labelling of this later species shows the weakness of our classification. Although there are no large ribs on the shell, the fingers make Aporrhais clearly different from the other pieces of 'simple gastropods'.

${ }^{78}$ Dobosi-VÁRI 1997, 74; MotTl 1942; GÁBORI 1969, 8-9, Taf. II, 2; MARKÓ 2007.

${ }^{79}$ At least 20 Lithoglyphus and 23 Melanopsis shells are known from this site: PROŠEK 1950, 179, Obr. 119; BÁRTA 1965, 122 , Tab XXV; BÁRTA 1972, 79, Obr 3. - This site is interpreted as a workshop from trinket production, see: PROŠEK 1950, 179; BÁRTA 1965 , 122; BÁRTA 1970, 208

${ }^{80}$ BÁRTA 1965, 124, Tab. XXXV, 1.

${ }^{81}$ Dobosi-Kövecses-VARga 1991, 239.
${ }^{82}$ Nitu-Carciumaru 2018; c.f. Beldiman-SzTANCs 2008, 72; CÂrciumaru-T,UȚUIANU-CÂRCIUMARU 2012.

${ }^{83}$ By sawing, see: D'ERrico et al. 1993, 250, Fig. 6D.

${ }^{84}$ In both cases the perforation is located between the aperture and the back of the shell, i.e. at the place E1-E2 following the system by TABORIN (1993, 170, Fig, 51).

${ }^{85}$ Probably trace of an attack by a decapod crustacean, see: GÖRÖG-SOMODY 1988, OLLÉ 1996, 18-19.

${ }^{86}$ At location E1b by TABORIN 1993.

${ }^{87}$ At location E3 by TABORIN 1993.

${ }^{88}$ HAHN 1969, 62, Bild 12,2.

${ }^{89}$ BÁRTA 1965, 122

${ }^{90}$ BÁRTA 1965, 125, XXXVI, 10-11. 


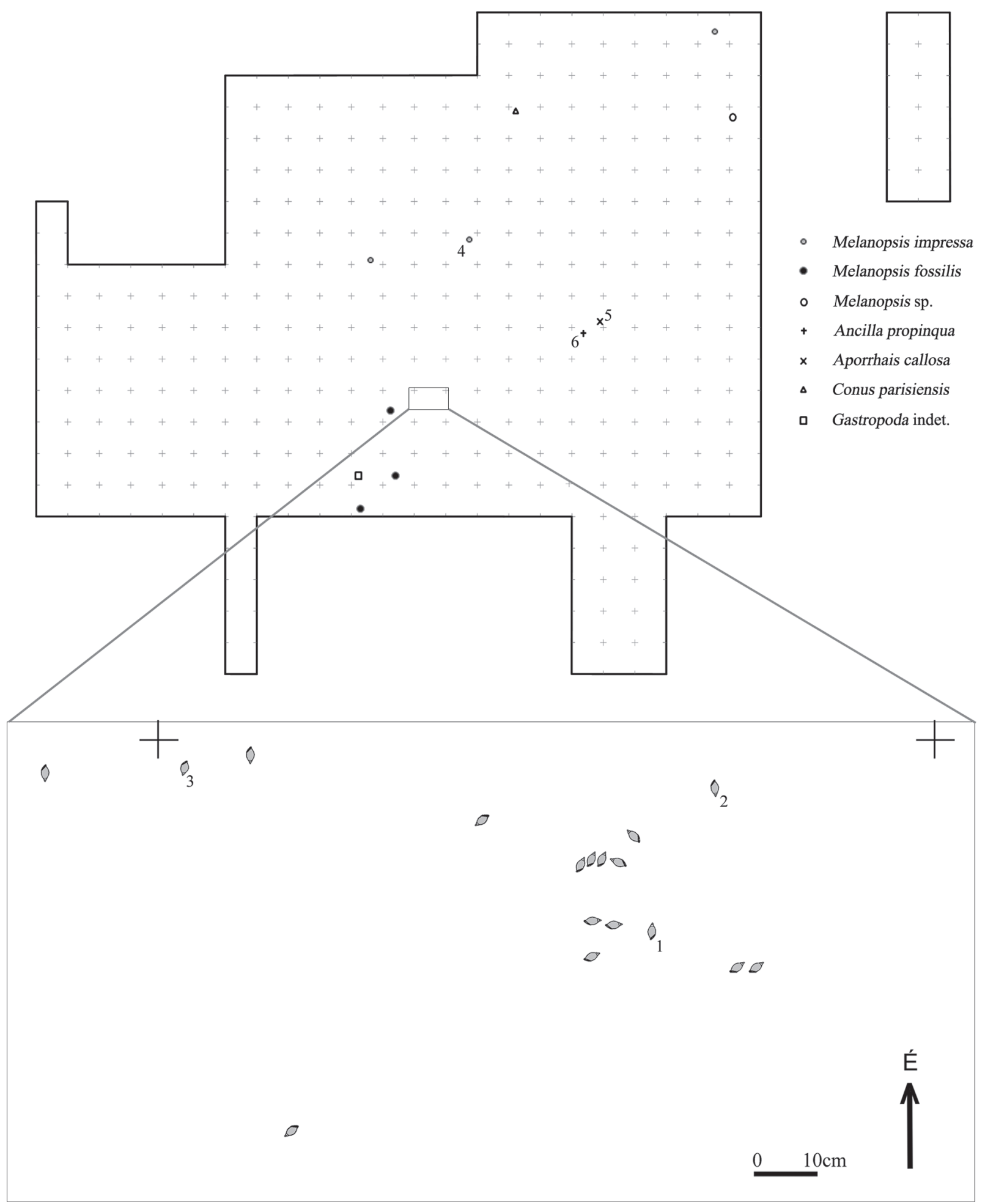

Fig. 10. Mogyorósbánya III. Spatial distribution of the simple gastropods (grid: 1 meter). For the legend see Fig. 11 


\section{'Other fossils'}

Twelve artefacts from Mogyorósbánya differ from the pieces discussed above. The burrow infill (Fig. 13.1) of unknown geological age and Eocene corals (Fig. 13.3-5), internal casts of gastropods (Fig. 13.2) and Nummulites (Fig. 13.6-7) were most probably collected because of their unusual form. ${ }^{91}$ With the exception of a single coral fragment these pieces were excavated in spot III, basically in the eastern and north-eastern part of the trench (Fig. 14). The role of these fossils are compared to the not modified Mesozoic brachiopods ${ }^{92}$ from Dolní Věstonice II, the Badenian coral from Milovice I, ${ }^{93}$ and the four Congeria shells from Poiana Cireşului. ${ }^{94}$ The not modified mammoth molar ${ }^{95}$ and probably the Nummulites ${ }^{96}$ found in the Epigravettian artefact-bearing layer of the Pilis-

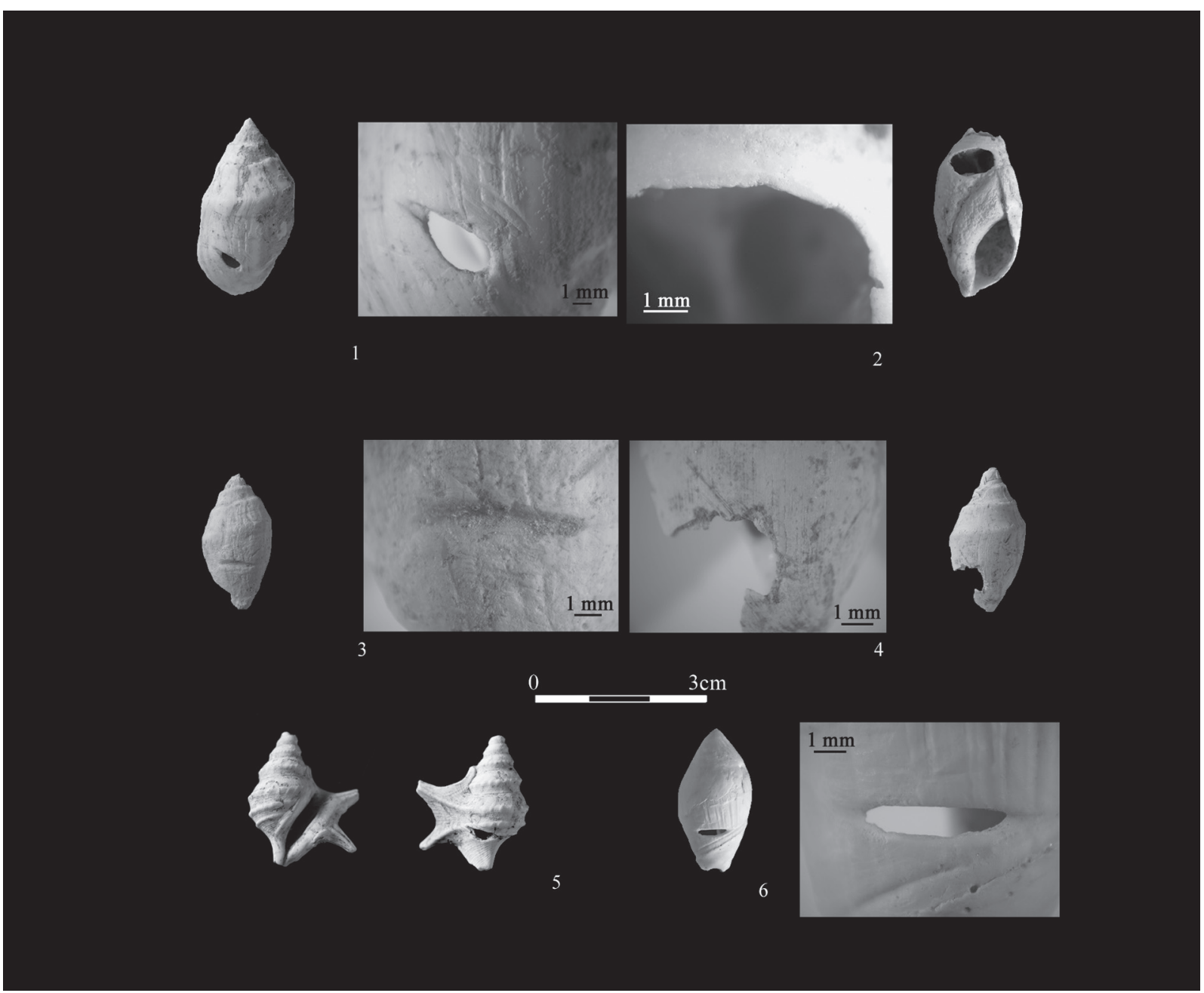

Fig. 11. Mogyorósbánya. Simple gastropods (1-4: Melanopsis impressa; 5: Ancilla propinqua; 6: Aporrhais callosa) with traces of manufacture and use

${ }^{91}$ The two refitted fragments of the internal cast Cerithium subcorvinum is the largest fossil of the Mogyorósbánya collection with the lenght of $75.5 \mathrm{~mm}$, the diameter of $29.5 \mathrm{~mm}$ and the weight of 69.95 g. From the Middle Eocene outcrops of Gánt and Dudar, the presence of considerably larger shells were reported (SzŐTs 1953, 50, 51; Strausz 1966, 30), showing the humans probably did not seek after the largest available specimen. - Following A. LEROI-GOURHAN (1965, 212-214) one can interpret the presence of these unusual pieces in the artefact-bearing layers as the first traces of scientific interest.
92 HLADILOVÁ 2016.

${ }^{93}$ Hladilová 1994, 24, Fig. 4.

94 BeLdimAN-SzTANCS 2008, 71; CÂRCIUMARU et al. 2004 125-126; CÂRCIUMARU et al. 2018, 248. - These shells, covered by traces of red ochre are interpreted as female representations.

${ }^{95}$ KORMOS-LAMBRECHT 1915, 422.

${ }^{96}$ Kormos-Lambrecht 1915, 339. - According to the excavator, however, these pieces could also have been transported to the cave in the craw of the birds. 


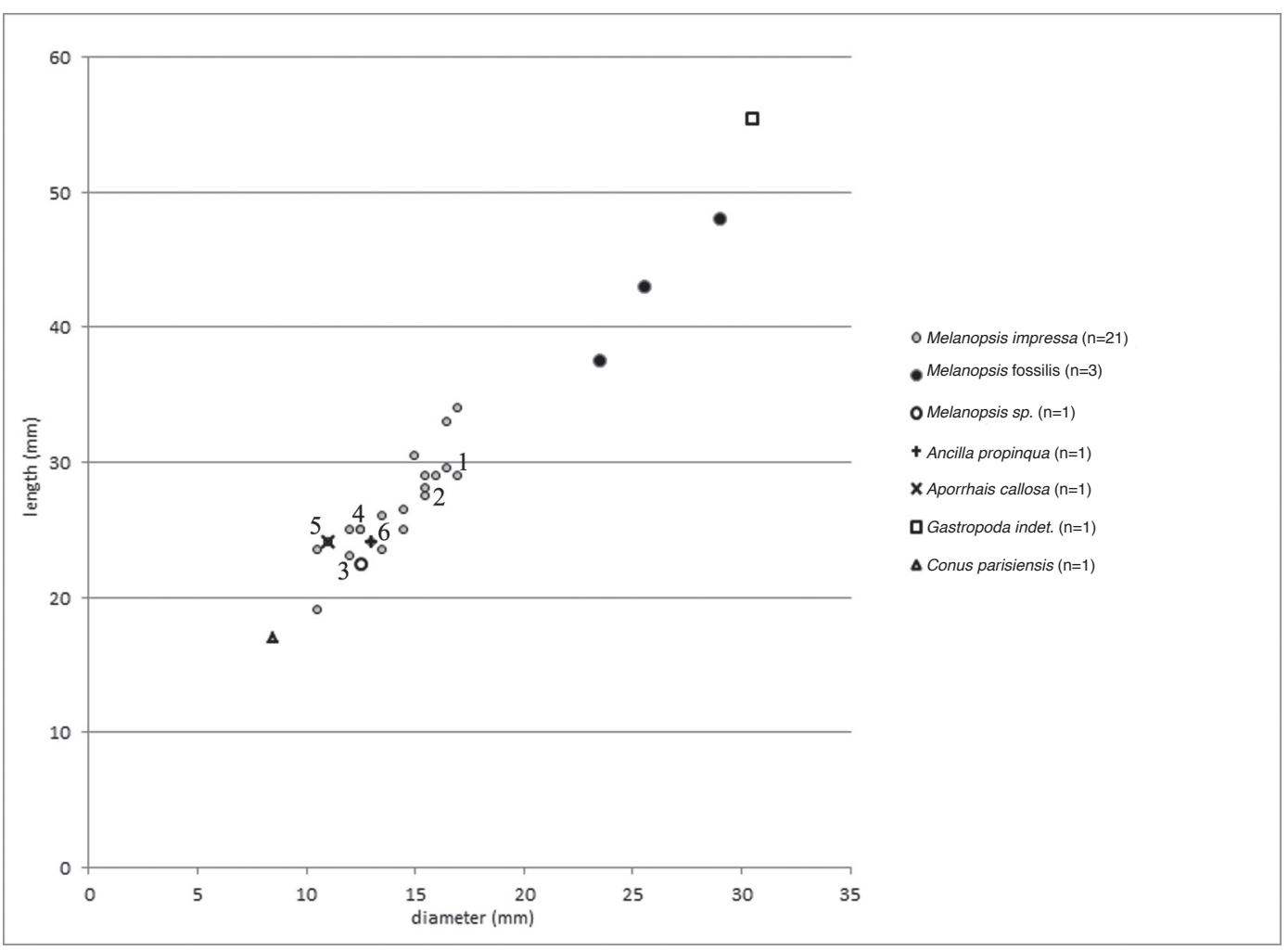

Fig. 12. Mogyorósbánya III. Metrical data of simple gastropods. For the legend see Fig. 11

szántó I rockshelter and the fossil shells found at Verseg were also interpreted as pieces which were collected as exotic items. ${ }^{97}$ Some manufactured Dentalium shells found in Esztergom and a single piece from Szob each filled with the original marine sediment may also belong to this category. Finally, the unmodified pebbles with a shape and dimensions of a pigeon's egg and a piece of clay mentioned from the first dwelling structure of the Ságvár site ${ }^{98}$ or the 119 globular concretions documented at Langmannersdorf ${ }^{99}$ were most probably collected by Prehistoric humans as unusual forms.

\section{NOTES ON THE SOURCE AREAS OF THE FOSSILS}

The analysis of the trinkets excavated at Esztergom raised certain questions about the source determination of some Badenian fossils, because three gastropod species are not known from the nearest outcrops at Szob and Letkés. ${ }^{100}$ As the lithic industry from this site was dominantly made of the extralocal Prut flint, ${ }^{101}$ the fossil trinkets were not necessarily collected from a source region lying close to the archaeological locality. In fact, Badenian deposits with well-preserved Dentalium shells were reported from the Vienna Basin (e.g. from the type locality at Baden) and Styria, as well as the environs of Sopron, Budapest, Szilvásvárad, the Mecsek Mountains and from the southern part of the Transylvania, ${ }^{102}$ too. Theoretically, each region can be considered as a potential source of the excavated fossils. A similar problem is emerged at the interpretation of the Oligocene molluscs found in the Mogyorósbánya assemblage: the sources of the Tympanotonos, Dentalium and Aporrhais specimens may suggest

${ }^{97}$ Magyar 1991b.

${ }^{98}$ GÁBORI-GÁBORI 1958, 22; GÁBORI 1959, 5, 12. - These artefacts, together with the crescent shaped pendant (or fragment of a ring) and a bone tool found in the same feature are not found among the catalogued pieces from the last excavations.

99 ANGELi 1953, Abb. 18.
${ }^{100}$ Conus antediluvianus, Surcula serrata and Genota ramosa valeriae: MAGYAR 1991a, 265. - The presence of this later species, however, was reported from the archaeological assemblage of Szob-Ipoly-part (CSEPREGHY-MEZNERICS 1956).

${ }^{101}$ Dobosi-Kövecses-VARga 1991; Dobosi 2010.

${ }^{102}$ Csepreghy-MeZnerics 1951, 80. 


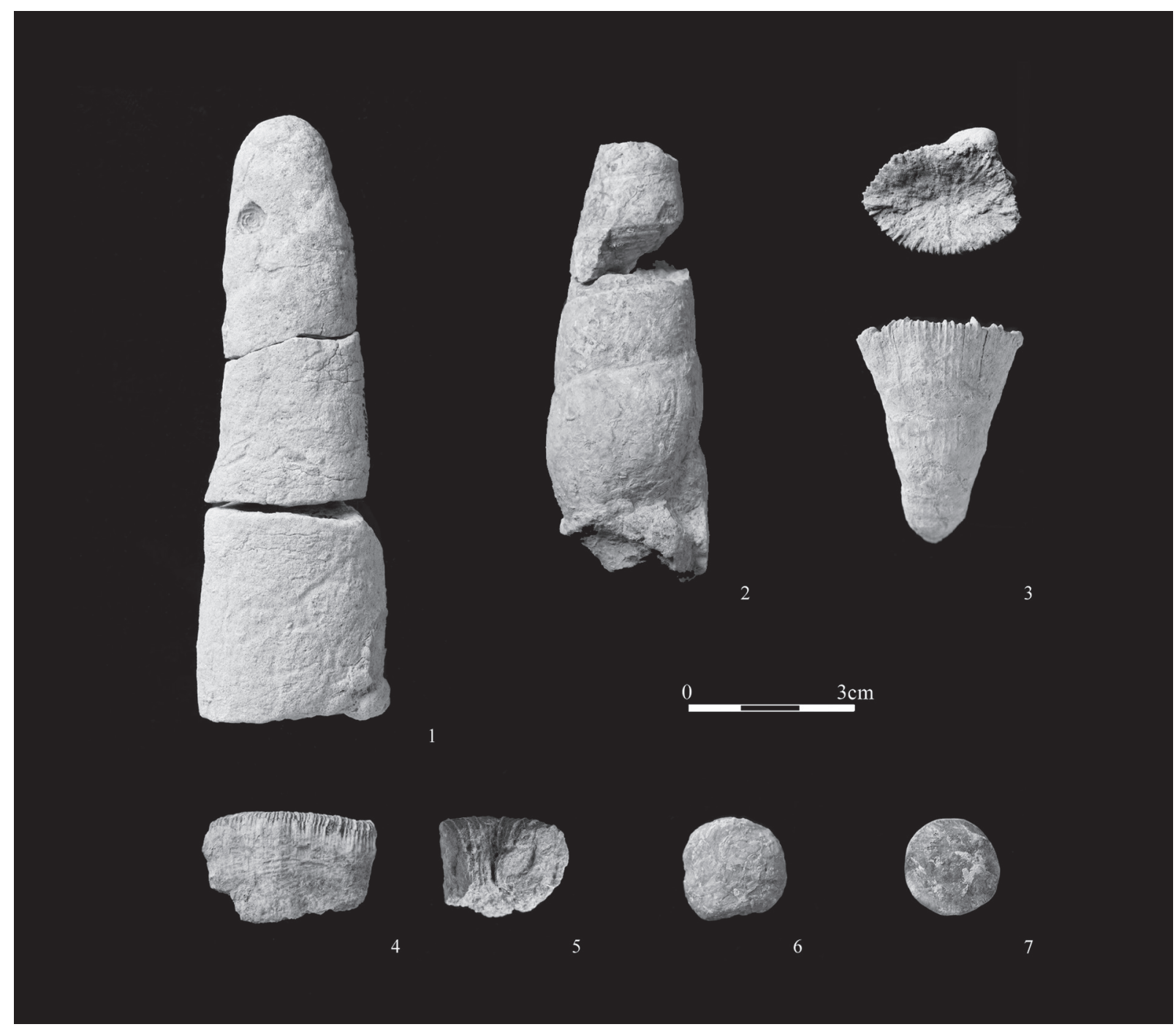

Fig. 13. Mogyorósbánya. 'Other fossils' from settlement spot II and III

(1: burrow infill, 2: Cerithium subcorvinum, 3: Circophyllia sp., 4-5: Trochosmilia sp., 6-7: Nummulites brongniarti)

for different source regions and different palaeo-communities, even if in the vicinity of Diósjenő the occurrence of each species is known. ${ }^{103}$

Generally speaking, it is possible, that although a given species, present in the archaeological layers were not recorded in paleontological papers, they may occur as a rare member of the fossil assemblages of a region. ${ }^{104}$ For instance, in the Máriahalom sandpit the different fossil-rich lenses and pockets sampled during the decades yielded faunas of slightly different composition; ${ }^{105}$ this way $17-21$ thousand years ago different geological layers with slightly different fossils could have been accessible for Prehistoric humans. ${ }^{106}$

On the other hand, the type locality of the Late Oligocene Egerian stage yielding Tympanatonos, Dentalium and Aporrhais shells is found in the former Wind brickyard in Eger ${ }^{107}$ lying at a distance of $135 \mathrm{~km}$ from the Mogyorósbánya site. Furthermore, the fauna collected from the Pannonian outcrop in the neighbouring Ostoros is al-

${ }^{103}$ BÁLDI 1973, 260-261, 267, 336

${ }^{104}$ About the possible role of the drifting algae, see: SZABÓ 1983, 206

${ }^{105}$ JANSSEN 1984.
${ }^{106}$ For instance this way, the outcrop at EsztergomSzentgyörgymezö yielding Dentalium and Aporrhais shells (KovÁCSVICZIÁN 2016), lying directly on the bank and in the bed of the Danube river was most probably not accessible during the Late Pleistocene.

${ }^{107}$ Telegdi-Roth 1914; BÁLdI 1973. 
most identical with the Tinnye material ${ }^{108}$ and from the nearby Noszvaj and Kács fossiliferous Eocene sediments (with Isis, Trochosmilia, Circophylia corals) ${ }^{109}$ were reported. As a total, the occurrence of each fossil species evidenced from the Mogyorósbánya site is known from a minor region in the south-western part of the Bükk Mountains. Importantly, these outcrops are found along a possible route leading from the northern part of Transdanubia to the obsidian sources in North-Eastern Hungary and South-Eastern Slovakia, which can be an important as 3.13\% of the Mogyorósbánya 'lithic assemblageś' are made of this volcanic glass. ${ }^{110}$

As a conclusion, we suggest that the data about the present day occurrences of a given fossil in the geological formations can be used only as an approximation to estimate the nearest sources of the shells found during the archaeological excavations. However, it is not possible to decide without further considerations if the studied pieces were collected from local sources or they were transported to the site from a larger distance. In the Mogyorósbánya assemblages the single Aporrhais and the few Dentalium shells were both manufactured and used, while only one Tympanotonos was drilled. These archaeological observations let us to suppose that former species and the Tympanotonos shells were collected from two distinct source areas, and that the latter formation was lying relatively closer (around $15 \mathrm{~km}$, e.g. at Máriahalom) to the archaeological site than the former one (more than $30 \mathrm{~km}$, at Diósjenő).

On the other hand, the coral and Nummulites remains, as well as the internal cast of gastropods are considered as collected from locally available Eocene sediments.

\section{NON-INTENTIONAL, OCCASIONAL AND SYSTEMATICAL COLLECTION}

In our view, the majority of these later species, ${ }^{111}$ represented by single, non-manufactured fossils were collected occasionally, on a not systematic way, probably during the lithic raw material procurement. For instance, in the Hejszoba vineyards, lying $2.5 \mathrm{~km}$ from the site, a surface outcrop of the Cretaceous grey chert pebbles, macroscopically similar to the main raw material of the excavated artefacts was mapped $;{ }^{112}$ from the same hill the occurrence of a number of Eocene fossils was also reported. ${ }^{113}$ Similarly, phyllite pebbles could have been found during the pebble raw material collection in the nearby terraces of the Danube river and the piece of amber, excavated in the southern section of spot III (Fig. 14) may belong the same category: in Silesia this fossil resin is found in the Pleistocene age end moraines, ${ }^{114}$ together with the excellent quality flint, well represented in the Mogyorósbánya assemblage.

The occurrence of very small fragments of the thick walled Ostrea shells in the artefact bearing layer is also linked to the raw material collection, however, in the absence of larger pieces it is interpreted as not intentional by products of the exploitation of Tertiary pebble-bearing sediments.

Finally, the selected ornamented and simple gastropods, partly excavated in little find concentrations were most probably introduced to the site after a systematic collection from single outcrops. ${ }^{115}$ The manufactured tubular fossils, the Ancilla and Aporrhais shells, and probably the two Bittium specimens, documented in spatially well limited parts of the excavated surface belong to the same group.

\section{...THE GREAT OCEAN OF TRUTH LAY ALL UNDISCOVERED BEFORE US}

The grave finds like Brno II may offer an easy starting point for the explanation of the pieces discussed in this paper. Beyond some basic conclusions, however, the interpretation can be rather doubtful, especially if one uses the phrases like magician or shaman. ${ }^{116}$ However, in 1966 the detailed documentation of a burial in Colombia

${ }^{108}$ JANKOVICH 1969.
${ }^{109}$ KolOSVÁRY 1956.
${ }^{110}$ MARKÓ 2017.
${ }^{111}$ Possibly with the exception of the Nummulites, see note 95.
${ }^{112}$ FÜLÖP 1958; GIDAI 1973.
${ }^{113}$ Tympanotonos calcaratus, $T$. diaboli, Diastoma roncanum, Ampullina perusta, Cerithium subcorvinum, and the genera Circophyllia, Trochosmilia, Ostrea, Nummulites and Bittium: SzŐTs 1956, 99, 100
114 NIEDŹWIEDZKI 2015.

${ }^{115}$ The sporadic occurrence of the Eocene Tympanotonos calcaratus and T. hungaricus remains compared to the numerous Oligocene T. margaritaceus shells, found in the same concentrations is interpreted by the differences in the occasional and systematic collection methods.

${ }^{116}$ Zotz 1951, 223-225; OLIVA 2000. 


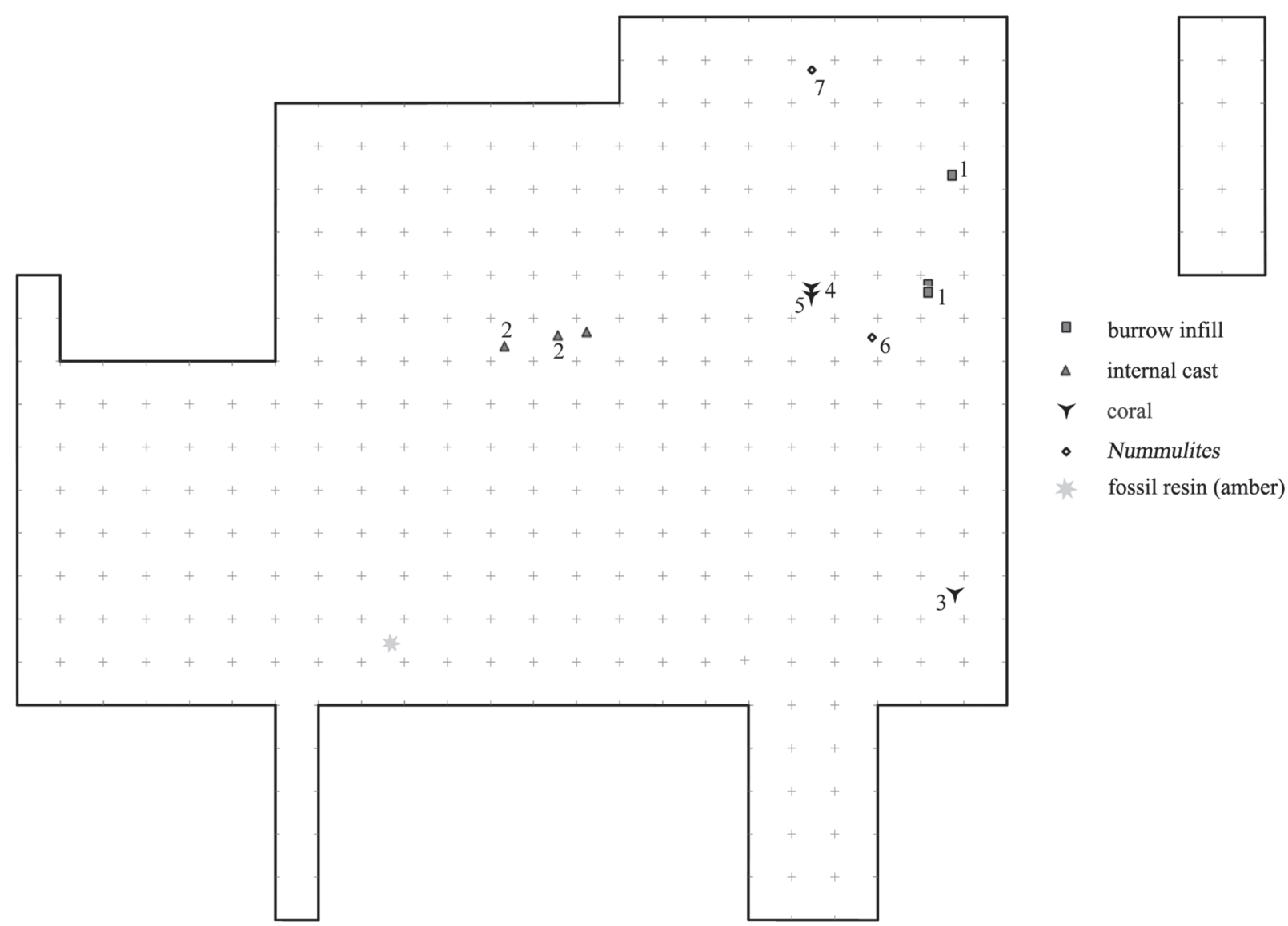

Fig. 14. Mogyorósbánya III. Spatial distribution of corals, Nummulites, burrow infills and internal casts of gastropods (grid: $1 \mathrm{~m}$ ). For the legend see Fig. 13

showed that the 'meaning' of little green stones and mollusc shells in a grave would not be decipherable for archaeologists or even for contemporary anthropologists who are not familiar with the symbolism and the rituals of the Kogi tribe. ${ }^{117}$ This way, the realistic interpretation of the not-perforated melanopsids excavated at the vertebral column of D.V. XIII individual ${ }^{118}$ in the triple burial of Dolní Věstonice II would be difficult or even impossible. The Mogyorósbánya assemblage was excavated in settlement context, which makes the explanations even more problematic; that is why in the following only some general conclusions are drawn.

1. The analysis showed that humans exploited different types of sources: the ancient Danube gravel for the phyllite pebbles, Eocene and Oligocene marine sediments and Pannonian lacustrine deposits for the fossils. The diversity of the origin of fossil remains is unique in the quasi-contemporaneous Pebble Gravettian and Epigravettian assemblages of the Danube Bend and the northern part of the Great Hungarian Plain, but it is similar to that one observed on the Gravettian sites in Moravia, where Badenian, Sarmatian and Pannonian fossils, each from the Vienna basin were regularly used. ${ }^{119}$ Moreover, fossils from the same stages, collected from the vicinity of the locality were found at Verseg-Kertekalja, ${ }^{120}$ too.

2. On the Mogyorósbánya site phyllite pebbles and various Eocene fossils were collected occasionally, together with the lithic raw materials from occurrences lying close to the site. The selected Oligocene and Pannonian species were, on the other hand, introduced to the settlement as a result of systematic collection from a distance of

${ }^{117}$ In the given case the bivalve shells represent the living members of the family, while a single gastropod shell is the symbolic 'husband' of the deceased maiden. - The observations by C. ReichelDolmatoff are cited by ELIADE 1976, 22-23.
${ }^{118}$ Klíma 1987, 57; HLadilová 2016.

${ }^{119}$ Hladilová 1994; Hladilová 2005; Hladilová 2011; HLADILOVÁ 2016.

${ }^{120}$ Magyar 1991b.

Acta Archaeologica Academiae Scientiarum Hungaricae 69, 2018 
at least $15-17 \mathrm{~km}$. However, it is not possible to estimate the length of the fossil transport, as the geological formations yielded the same typical fossil shells on a large territory, occasionally in each region of the Carpathian Basin.

3. Based on the intuitive morphological classification of the Mogyorósbánya fossils, both ornamented and simple gastropods, and in a lesser extent, tubular fossils were equally searched by the humans. This is similar to the pattern observed in the collection from Szob, from the lower layer of Pilismarót-Bitóc and probably from the Gravettian or Epigravettian locality of Ratnovce (Western Slovakia), ${ }^{121}$ although in these later collections bivalve shells are relatively well represented. At the same time, on the Epigravettian site of Pilismarót-Pálrét, EsztergomGyurgyalag and the upper layer at Pilismarót-Bitóc the scaphopods clearly dominate the assemblages.

4. In the excavated part of the settlement spot III three larger mollusc concentrations are observed. In the southern part of the trench Pannonian melanopsids were documented, tentatively interpreted as elements of a necklace. Importantly, the single amber piece was found also in this part of the site. In the eastern part of the trench occasionally on-site fragmented ornamented gastropods were excavated, together with a unique rock crystal artefact and two perforated simple gastropods. In last concentration Eocene and Oligocene Tympanotonos species, including the single manufactured piece were found. Finally, phyllite artefacts, tubular and 'other' fossils are largely found in the eastern and north-eastern part of the excavated trench, however, without evident concentration.

In the future these spatial data should be compared to the distribution of the red ochre lumps and grains, ${ }^{122}$ the different lithic raw material categories like the northern silicite (flint) variants and the obsidian and of the excavated fireplaces.

5. Except for the Dentalium and worm tube fragments very few pieces show traces of human modification. On the simple gastropods sawing and scraping, on a single ornamented Tympanotonos shell drilling is observed.

6. The phyllite pebbles were also manufactured by scraping, grooving and incisions, however, the function of the fragmented artefacts is not known for the time being.

7. The non-utilitarian assemblage from Mogyorósbánya is similar to the Pilismarót-Pálrét collection, where fossil trinkets, incised stone artefacts and a piece of amber was documented. ${ }^{123}$ The lithic industry of this latter site is, however, classified as belonging to the Epigravettian ${ }^{124}$ and the radiocarbon dates, ${ }^{125}$ the lithostratigraphic and malacological analysis ${ }^{126}$ show that the artefact bearing layer is clearly younger than the find horizon of Mogyorósbánya.

Moreover, fossil shells and pieces of amber were excavated at Langmannersdorf and in the Gravettian I (earlier: Epigravettian) layer of Poiana Cireşului, too, and from the later site incised artefacts, from the former ochre piece with sharp edge was also published. ${ }^{127}$ This similarity of the roughly contemporaneous non-utilitarian assemblages raised the necessity to compare the lithic industries of these sites, too.

\section{ACKNOWLEDGEMENT}

A. Dulai was supported by Hungarian Scientific Research Fund (OTKA K112708).

${ }^{121}$ KAMinSKÁ 2014, Obr. 90,3-16.

${ }^{122}$ A melanopsid was excavated in a little red-coloured spot lying 5 meter from the main concentration, however, on the surface of this shell few traces of ochre were observed. Similarly, no red coloration is observed on the single Dentalium shell from settlement spot II, which was also found in an ochre spot. Probably in both cases the removal of the calcium-carbonate precipitation destroyed the original surface of the mollusc. From Esztergom-Gyurgyalag the inner and the outer surface of some tusk shells are covered by red film, as well as the single bivalve shell from Ságvár.

${ }^{123}$ Both localities are identified as satellite camps (DoвosI 1992, 9-10), which is seemingly in contradiction with the presence of non-utilitarian artefacts. However, as the recently excavated Pavlov VI site shows, the occurrence of these pieces are not restricted to the rich aggregation sites (SvoBodA-FrouZ 2011). In fact, the fossil shells were not associated by lithic artefacts in the Csővár cave (PATAY 1932) and rather uncharacteristic industry, typical for lithic workshops was excavated at Verseg (DoBosi 1991).

${ }^{124}$ Dobosi et al. 1983; DoBOsI 2006.

${ }^{125} 13.130 \pm 100$ B.P and $16.000 \pm 200$ B.P: SÜMEGI-

Krolopp 2000, Table 1; Dobosi-SZÁnTó 2003; Dobosi 2006, 37.

${ }^{126}$ SÜMEGI-KROLOPP 2000.

${ }^{127}$ CÂrCIUMaru et al. 2018. 
REFERENCES

ABSOLON-KLÍMA 1977

ANGELI 1953

BÁLDI 1973

BÁRTA 1965

BÁRTA 1970

BÁRTA 1972
= K. Absolon-B. Klíma: Předmostí. Ein Mammutjägerplatz in Mähren. Academia, Praha 1977.

= W. ANGELI: Der Mamutjägerhalt von Langmannersdorf an der Perschling. MPK 6 (1952-1953) $3-118$

= T. BÁLDI: Mollusc Fauna of the Hungarian Upper Oligocene (Egerian) - Studies in stratigraphy, palaeoecology, palaeogeography and systematics. Budapest 1973.

= J. BÁRTA: Slovensko v staršej a strednej dobe kamennej (Die Slowakei in der älteren und mittleren Steinzeit). Bratislava 1965.

= J. BÁRTA: Zur Problematik der Gravettezeitlichen Besiedlung der Slowakei. SlA 18/2 (1970) 207-215.

= J. BÁRTA: Jaskyňa Čertova pec pri Radošine - Die Höhle Čertova pec bei Radošina. Slovenský Kras 10 (1972) 73-85.

BARTHA-KeCsKemÉtinÉ KÖRMENDY 1963 = F. BARTHA-A. KeCsKemÉTINÉ KÖRMENDY: Biosztratigráfiai vizsgálatok a Dorogi-medence eocén korú molluszkumos képződményein - Examen biostratigraphique des formations éocènes à Mollusques du Bassin de Dorog. FtK 93 (1963) 451-465.

BELDIMAN-SZTANCS 2008

= C. BeldimAN-D.-M. SzTANCs: Espace, temps, symbole dans la Préhistorie de la Moldavie, Roumanie: art mobilier au Paléolithique Supérieur. In: Établissements et habitations Préhistoriques. Structure, organisation, symbole. Actes du Colloque de Iaşi 10-12 décembre 2007. Éd.: V. Chirica, M.-C. Văleanu. Bibliotheca Arheologica Moldaviae 9 (2008) 65-98.

CÂRCIUMARU-TUTUUIANU-

CÂRCIUMARU 2012

CÂRCIUMARU et al. 2004

CÂRCIUMARU et al. 2018

CSEPREGHY-MEZNERICS 1951

CSEPREGHY-MEZNERICS 1956

DoBosi 1974

DoBosi 1985

DoBosi 1991

DoBOsI 1992

DoBosi 1993

DoBosi 2000

DoBosi 2002

DoBosi 2006

DoBosi 2010

DoBosi 2011

DoBosi 2016

DOBOSI-KÖVECSES-VARGA 1991
= M. CÂRCIUMARU-M. TUTUUIANU-CÂRCIUMARU: The oldest snail (Lithoglyphus naticoides) necklace discovered in Romania in the Gravettian III stratum of Poiana Cireşului-Piatra Neamț [25.760 160 $-27.321 \pm 234$ B.P. (31.969 ka)]. Annales d'Université Valahia Targoviste, Section d'Archeologie et d'Histoire 14/1 (2012) 19-42.

= M. CÂrciumaru-M. Margarit-L. Nita-M. Angheliu-M. CosaC-O. Carstina: Les décovertes d'art mobilier Paléolithique de Poiana Cireşul-Piatra Neamt (Roumanie). In: La spiritualité. Actes du colloque international de la Commission 8 de l'UISPP, 10-12 décembre 2003. Dir.: M. Otte. ERAUL 106. Liège 2004, 123-126.

= M. CÂrciumaru-E.-C. Niţu-N. Goutas-M. Otte-O. Cîrstina-T. Sava-M. Straticiuc-M.-M. Manea-F. I. Lupu-M. Leu-A. Nicolae-T. Neagu: Parures et objets d'art du Gravettien recent de Poiana Cireşului-Piatra Neamţ (Roumanie). L'Anthropologie 122 (2018) 220-260.

= I. CSEPREGHY-MEZnERICS: Untersuchung der dentalien aus Alsónémedi. ActaArchHung 1 (1951) 79-80

= I. CSepreghy-Meznerics: A szobi és letkési puhatestű fauna - Die Molluskenfauna von Szob und Letkés. MÁFIÉ 45/2 (1956) 363-474.

= V. Dobosi: Adatok a Bodrog-völgy öskőkorához - Contributions to the Palaeolithic Age of the Bodrog valley. FolArch 25 (1974) 9-32.

= V. Dobosi: Jewelry, musical instruments and exotic objects from the Hungarian Paleolithic. FolArch 36 (1985) 7-32.

= V. Doвоsı: Paleolit telep Verseg-Kertekalján - Palaeolithic settlement at Verseg-Kertekalja. StComit 21 (1991) 73-81.

= V. Dobosi: A new Upper Palaeolithic site at Mogyorósbánya. ComArchHung 1992, 5-17.

= V. Doвosi: Jászfelsőszentgyörgy-Szunyogos, Upper Paleolithic locality. Tisicum 8 (1993) 41-60.

= V. Dobosi: Archaeological investigations at Bodrogkeresztúr-Henye. In. Bodrogkeresztúr-Henye (NE-Hungary) Upper Palaeolithic Site. Ed. V. T. Dobosi. Magyar Nemzeti Múzeum, Budapest 2000, $5-111$.

= V. Doвosi: Mogyorósbánya, Újfalusi dombok felső paleolit telep - Mogyorósbánya, Újfalusi dombok, Upper Palaeolithic site. In: Régészeti kutatások Magyarországon - Archaeological Investigations in Hungary 1999. Ed.: E. Marton. Budapest 2002, 5-14.

$=$ V. Dobosi: Gravetti lelöhelyek Pilismarót környékén - Gravettian sites around Pilismarót. FolArch 52 (2005-2006) 21-48.

$=$ V. Dobosi: Prut flint on the top: Esztergom-Gyurgyalag. In: Transkarpatskie Kontakty kulturowe w epoce kamienia, brązu i wczesnej epoce żelaza. Red.: J. Gancarski. Muzeum Podkarpatskie w Krośnie, Krosno 2010, 99-113.

= V. Dobosi: Mogyorósbánya, felső paleolit telep, új eredmények - Upper Paleolithic site at Mogyorósbánya. New findings. In: Corolla museologica Tibor Kovács dedicata. Eds.: E. Tóth, I. Vida. Budapest 2011, 535-558.

$=$ V. Doвosi: Tradition and modernity in the lithic assemblage of Mogyorósbánya Late Palaeolithic site. ActaArchHung 67 (2016) 5-30.

= V. DoBosi-E. KövecsES-VARGA: Upper Palaeolithic site at Esztergom-Gyurgyalag. ActaArchHung 43 (1991) 233-255. 
DoBOSI-SZÁNTÓ 2003

DoBosi-VÁRI 1997

DoBosi et al. 1983

DULAI 1996

DULAI 2007

ELIADE 1976

D’ERrico et al. 1993

FÖLDVÁRI 1992

FÜLÖP 1958

GÁBORI 1959

GÁBORI 1964

GÁBORI 1969

GÁBORI-GÁBORI 1957

GÁBORI-GÁBORI 1958

GÁBORI-CsÁNK 1983

GIDAI 1973

GÖRÖG-SOMODY 1988

HAHN 1969

HLADILOVÁ 1994

HLADILOVÁ 2005

HLADILOVÁ 2011

HLADILOVÁ 2016

HROMADA 1998

HromadA-ŽEmLA 2000

JANKOVICH 1969

JÁNOSSY et al. 1957
= V. DoBosi-Zs. SzÁNTó: A gravetti időszak hagyományos és radiokarbon koradatai (Traditional and radiocarbon dates of the Gravettian period). ArchÉrt 128 (2003) 5-16.

= V. DobosI-Á. VÁRI: Horváth Adolf János régészeti feljegyzései - Archaeological notes by Adolf János Horváth. FolArch 46 (1997) 47-91.

= V. Dobosi-I. VÖrös-E. Krolopp-J. SZABÓ-Á. Ringer-F. SchweITZER: Upper Palaeolithic settlement in Pilismarót-Pálrét. Archaeological explorations. ActaArchHung 35 (1983) 287-311.

= A. Dular: Taxonomic composition and palaeoecological features of the Early Badenian (Middle Miocene) bivalve fauna of Szob (Börzsöny Mts, Hungary). AnnHM 88 (1996) 31-56.

= A. Dulai: Late Palaeolithic fossil collectors: small piles of molluscs at Szob (Börzsöny Mts, North Hungary). FolArch 53 (2007) 23-25.

= M. EliADE: Histoire des croyances et des idèes religieuses. I.: De l'âge de la pierre aux mystères d'Eleusis. Payot, Paris 1976.

= F. D'ERrICO-J. JARDÓN-GINER-B. SOLER-MAYOR: Critères à base expérimentale pour l'étude des perforations naturelles et intentionelles sur coquillages. In: Traces et fonction: les gestes retrouvés. Colloque international de Liège. Réd.: P. C. Anderson, S. Beyries, M. Otte, H. Plisson. ERAUL 50. Liège 1993, 243-254.

= M. FöLDVÁRI: Analysis of amber from Mogyorósbánya. ComArchHung 1992, 16-17.

= J. FÜLÖP: A Gerecsehegység krétaidőszaki képződményei-Die kretazeischen Bildungen des Gerecse-Gebirges. Geologia Hungarica, Series geologica 2. Magyar Állami Földtani Intézet, Budapest 1958.

= M. GÁBORI: A ságvári paleolitikus telep újabb ásatásának eredményei (Les résultats des fouilles récemment effectuées dans la station Paléolithique de Ságvár). ArchÉrt 86 (1959) 3-19.

= M. GÁBORI: A késői paleolitikum Magyarországon [The Late Palaeolithic in Hungary]. RégTan 3. Akadémiai Kiadó, Budapest 1964.

= M. GÁBORI: Paläolithische Schnecken-Depots von Szob. ActaArchHung 21 (1969) 3-11.

= M. GÁBORI-V. GÁBORI: Études archéologiques et stratigraphiques de Hongrie. ActaArchHung 8 (1957) 3-117.

= M. GÁBORI-V. GÁBORI: Der erste paläolithische Hausgrundriss in Ungarn. ActaArchHung 9 (1958) 19-34.

= V. GÁBori-CsÁNK: La grotte Remete «Felső» (Supérieur) et le «Szeletien de Transdanubie». ActaArchHung 35 (1983) 249-285.

= L. GIDAI: Mogyorósbánya - a Dorogi-medence földtani térképe, 10 000-es sorozat. Magyar Állami Földtani Intézet, Budapest 1973.

= Á. GöRÖG-A. Somody: Trace fossils on Badenian (Miocene) Gastropods from Várpalota, Hungary. AUB Sectio Geologica 28 (1988) 121-156.

= J. HAHn: Gravettien-Freilandstationen im Rheinland: Mainz-Linsenberg, Koblenz-Metternich und Rhens. BJ 169 (1969) 44-87.

= Š. HLadILOvÁ: Nálezy třetiohorních fosilií na mladopaleolitické stanici Milovice (Jižní Morava, Česká Republika) - Les fossiles tertiaires trouvés à la station du Paléolithique Supérieur de Milovice (Moravie du Sud, République Tchèque). ČMM 79 (1994) 15-29.

= Š. HladilovÁ: Tertiary fossils, especially molluscs. In: Pavlov I Southeast. A window into the Gravettian lifestyles. Ed.: J. A. Svoboda. The Dolní Věstonice studies 14. Academy of Sciences of the Czech Republic, Institute of Archaeology at Brno - Polish Academy of Sciences, Institute of Systematics and Evolution of Animals, Brno 2005, 374-390.

$=$ Š. HLadilová: Tertiary and Quaternary molluscs from Pavlov VI. In: Pavlov, excavations $2007-$ 2011. Ed.: J. Svoboda. The Dolní Věstonice studies 18. Academy of Sciences of the Czech Republic, Institute of Archaeology at Brno - Polish Academy of Sciences, Institute of Systematics and Evolution of Animals, Brno 2011, 54-60.

= Š. Hladilová: Tertiary molluscs. In: Dolní Věstonice II: Chronostratigraphy, Paleoethnology, Paleoanthropology. Ed.: J. Svoboda. The Dolní Věstonice studies 21. The Academy of Sciences of the Czech Republic, Institute of Archaeology Brno, Paleolithic and Paleoethnology Research Center Dolní Věstonice. Brno 2016, 323-327.

= J. HromadA: Gravettienske sídliská v Moravanoch nad Váhom a ich miesto vo vývoji mladého paleoliu strednej Europy (Gravettian sites in Moravany nad Váhom and their place in development of the Upper Palaeolithic in Central Europe). S1A 44/2 (1998) 145-167.

= J. HROMADA-M. ŽEMLA: Gravettienske sídliska v Hubine (Gravettian settlement in Hubina). AVANS 1998 (2000) 88-90.

= I. JANKOVICH: Alsópannon fauna Ostorosról (Eine unterpannonische Fauna von Ostoros). FtK 99/1 (1969) 81-90.

= D. JÁNOSSY-S. KRETZOI-VARRóK-M. Herrmann-L. VÉRTES: Forschungen in der Bivakhöle, Ungarn. Eiszeitalter und Gegenwart 8 (1957) 18-36. 
JANSSEN 1984

KAMINSKÁ 2014

KLÍMA 1987

KoLOSVÁRY 1949

KOLOSVÁRY 1956

KoRMOS-LAMBRECHT 1915

KORPÁS-HÓDI 1983

KovÁCS-VICIÁN 2016

LACZKÓ et al. 1930

LEROI-GOURHAN 1965

LŐRENTHEY 1902

Magyar 1991a

MAGYAR 1991b

MAGYAR et al. 2017

MARKÓ 2007

MARKÓ 2017

MAKOWSKI 1892

MiHÁLY 2011

MotTL 1942

MÜLLER-MAGYAR 1992

MÜLLER et al. 2007

NeUGeBAUER-MAResCH et al. 2016

NIEDŹWIEDZKI 2015

NitU-CARCIUMARU 2018

OLIVA 2000
= A. W. JANSSEN: Late Oligocene molluscs from a sand-pit near Máriahalom (Hungary): A preliminary study. AUB Sectio Geologica 24 (1982) [1984] 109-149.

= L. KAMINSKÁ: Staré Slovensko. 2.: Paleolit a mezolit (Ancient Slovakia. 2: Palaeolithic and Mesolithic). Archeologický Ústav Slovenskej Akadémie Vied, Nitra 2014.

= B. KLÍMA: Das Jungpaläolithische Massengrab von Dolní Věstonice. Vorläufige Mitteilung. Quartär 37/38 (1987) 53-62.

= G. KolosvÁRY: Dunántúli eocén-korallok - The Eocene corals of the Hungarian Transdanubian province. FtK 79 (1949) 141-242.

= G. KolosvÁRY: A Bükkhegység eocén koralljai - Эоценовые кораллы гор Бюкк. FtK 86 (1956) $67-85$.

= T. Kormos-K. LAmBrecht: A Pilisszántói kőfülke. Tanulmányok a postglaciális kor geologiája, ősipara és faunája köréből (Die Felsnische Pilisszántó. Beiträge zur Geologie, Archäologie und Fauna der Postglazialzeit). M. Kir. Földt. Intézet Évkönyve 23 (1915) 305-498.

= M. KoRPÁs-HódI: Palaeoecology and biostratigraphy of the Pannonian Mollusca fauna in the northern foreland of the Transdanubian Central range. Annals of the Hungarian Geological Institute 66 (1983) 1-163.

= Z. KovÁCs-Z. Vicián: A new Egerian (Upper Oligocene-Lower Miocene) gastropod fauna from the Esztergom Basin (NE Transdanubia, Hungary). FtK 146/3 (2016) 233-256.

= D. LACZKÓ-I. GAÁL-F. HollendonNER-J. HillEBRAND: A ságvári felső diluviális lösztelep (Lössmagdalénien-Fundstelle von Ságvár). ArchÉrt 44 (1930) 213-220, 302-304.

= A. Leroi-Gourhan: Le geste et la parole. II.: La mémoire et les rhytmes. Éd. Albin Michel, Paris 1965.

= I. LŐRENTHEY: Die pannonische Fauna von Budapest von Emerich Lőrenthey. Paläontographica 48. Stuttgart 1902.

= I. MagYAR: Palaeolithic trinkets in Esztergom-Gyurgyalag. ActaArchHung 43 (1991) 265-566.

= I. MAGYAR: Harmadkori puhatestüek maradványai Verseg-Kertekalja lelőhelyen (Tertiary fossil molluscs from the Palaeolithic site of Verseg-Kertekalja). StComit 21 (1991) 78

= I. Magyar-O. Sztanó-G. Csillag-Zs. Kercsmár-L. Katona-Z. Lantos-I. R. Bartha-L. FODOR: A Gerecse pannóniai puhatestűi és lelőhelyeik: rétegtan, őskörnyezet és fejlődéstörténet (Pannonian molluscs and their localities in the Gerecse Hills, Transdanubian Range: stratigraphy, palaeoenvironment, geological evolution). FtK 147/2 (2017) 149-176.

= A. Markó: The Upper Palaeolithic site at Szob. FolArch 53 (2007) 7-22.

= A. MARKó: Use of obsidian during the LGM: case studies from the Pebble Gravettian sites in Hungary. Archeometriai Mühely 17/3 (2017) 131-142.

= A. MaKowski: Der diluviale Mensch im Löss von Brünn. MAG 22 (1892) 73-84.

= J. MıнÁLY: Mogyorósbánya-Újfalusi-dombok felsőpaleolit lelőhelyről származó okkerkavics, illetve lösz-okker porminták FTIR és FT-Raman vizsgálata (FTIR and FT-Raman investigations on the ochre pebble and loess samples from the Upper Palaeolithic site of Mogyorósbánya). In: Corolla museologica Tibor Kovács dedicata. Eds: E. Tóth, I. Vida. Magyar Nemzeti Múzeum, Budapest 2011, 554-557.

= M. MotTL: Adatok a hazai ó és újpleisztocén folyóteraszok emlősfaunájához - Beiträge zur Säugertierfauna der unngarischen alt- und jungpleistozänen Flussterrassen. M. Kir. Földt. Int. Évkönyve 36/2 (1942) 1-70.

= P. MüLleR-I. Magyar: A Prosodacnomyák rétegtani jelentősége a Kötcse környéki pannóniai s.1. üledékekben (Stratigraphic significance of the Upper Miocene lacustrine cardiid Prosodacnomya, Kötcse section, Pannonian Basin, Hungary). FtK 122/1 (1992) 1-38.

= P. M. MülleR-I. CzICZER-I. Magyar: Tata, Baji úti és Agostyáni úti agyagbányák. Felső-miocén (pannóniai emelet), Száki Formáció (Tata, clay pits in the Agostyán and Szomód street: Upper Miocene (Pannonian Stage), Szák Formation). In: Őslénytani kirándulások Magyarországon és Erdélyben. Eds: J. Pálfy, P. Pazonyi. Hantken Kiadó, Budapest 2007, 47-51.

= Ch. Neugebauer-Maresch-T. Einwögerer-J. Richter-A. Maier-S. T. Hussain: KammernGrubgraben. Neue Erkenntnisse zu den Grabungen 1985-1994. ArchA 100 (2016) 225-254.

$=$ R. NIEDŹWIEDZKI: Amber occurrences in Silesia. In: Amberif 2015. The $22^{\text {th }}$ seminar on "Succinite and selected fossil resins of Europe: localities, properties, archaeology”. Gdańsk 27 March 2015. Gdańsk-Warsaw 2015, 23-27.

= E.-C. NitU-M. CARCIUMARU: Group identity and social networks in Gravettian. The case of perforated shells from Poiana Cireşului site, North-eastern Romania. Book of abstracts, 18th UISPP World Congress, Paris, June 2018. Paris 2018, 955

$=$ M. Oliva: The Brno II Upper Palaeolithic burial. In: Hunters of the Golden Age. The Mid Upper Palaeolithic of Eurasia 30,000-20,000 BP. Eds: W. Roebroeks, M. Mussi, J. Svoboda, K. Fennema. University of Leiden, Leiden 2000, 143-153. 
OLLÉ 1996

PAZONYI 2006

PATAY 1932

PÉCSI 1975

PRoŠEK 1950

SENEŠ 1958

STRAUSZ 1951

STRAUSZ 1966

STRAUSZ 1974

SÜMEGI-KROLOPP 2000

SvobodA-Frouz 2011

SzABó 1983

SZŐTS 1953

SzŐTs 1956

TABORIN 1993

TELEGDI-RoTH 1914

VÉRTES 1965

ZoTZ 1951

ZOTZ-VLK 1939
$=$ R. OLLÉ: Életnyomok és patológiás elváltozások az unyi homokbányában gyüjtött puhatestűek mészvázain - Trace fossils and palaeopathological phenomena on the shells of molluscs collected at Uny sandpit (Egerian, Mány-Zsámbék Basin, Hungary). Malakológiai Tájékoztató/Malacological Newsletter 15 (1996) 11-27.

= P. PAZONYI: A Kárpát-medence kvarter emlősfauna közösségeinek paleoökológiai és rétegtani vizsgálata [Palaeoecological and stratigraphic investigations of the Quaternary mammal faunas in the Carpathian Basin]. Manusript, Diss., Budapest 2006.

= P. PATAY: Újabb ősembernyomok Magyarországon [Further traces of the Prehistoric humans from Hungary]. TtK 64 (1932) 239-242.

= M. PÉCSI: A magyarorországi löszszelvények litosztratigráfiai tagolása (Lithostratigraphical subdivision of the loess sequences in Hungary). FrK 3-4 (1975) 217-230.

= F. ProšEK: Zjišt’ovací výzkum na paleolitické stanici v Moravanech na Slovensku (Fouilles de la station paléolithique de Moravany, Slovaquie). AR 2 (1950) 175-183, 290-291.

= J. SEnEŠ: Pectunculus-Sande und Egerer Faunentypus im Tertiär bei Kováčov im Karpatenbecken. Geologické Práce, Monografická séria 1. Košice 1958.

= L. STRausz: Földtani vizsgálatok Kisbér és Tata környékén (Geologische Beobachtungen in der Umgebung von Kisbér and Tata, Transdanubien). FtK 81 (1951) 284-292.

= L. STRausz: Dudari eocén csigák (Die Eozängastropoden von Dudar in Ungarn). GHP 33 (1966) $1-148$.

= L. STRAUSZ: Neszmélyi eocén puhatestüek (Die Eozänmollusken von Neszmély, Ungarn). GHP 38 (1974) 1-158.

= P. SÜMEGI-E. KROLOPP: Palaeoecological reconstruction of the Ságvár-Lascaux interstadial (Upper Weichselian). In: A la recherche de l'Homme Préhistrorique. Dir.: Zs. Mester, Á. Ringer. ERAUL 95. Liège 2000, 103-111.

= J. Svoboda-M. Frouz: Symbolic objects and items of decoration. In: Pavlov, excavations $2007-$ 2011. Ed.: J. Svoboda. The Dolní Věstonice studies 18. Academy of Sciences of the Czech Republic, Institute of Archaeology at Brno - Polish Academy of Sciences, Institute of Systematics and Evolution of Animals, Brno 2011, 200-206.

= J. SzABÓ: The origin of the Pilismarót-Pálrét Palaeolithic trinkets. ActaArchHung 35 (1983) 306

= E. SzŐTs: Magyarország eocén puhatestűi. I.: Gántkörnyéki eocén puhatestüek - Mollusques éocénes de la Hongrie. 1.: Les mollusques éocénes des environs de Gánt. GHP 22. Budapest 1953.

= E. SzŐTS: Magyarország eocén (paleogén) képződményei - rétegtani és ösföldrajzi tanulmány L’Éocéne (Paléogéne) de la Hongrie. Étude stratigrpahique et paléogéogrphique. GHP 9 (1956) 1-249. = Y. TABORIN: La parure en coquillage au Paléolithique. GalliaPh Suppl. 29. Paris 1993.

= K. Telegdi-Roth: Eine oberoligozäne Fauna aus Ungarn. Geologica Hungarica 1/1 (1914) 1-77.

= L. VÉRTES: "Lunar Calendar" from the Hungarian Upper Paleolithic. Science 149/3686 (1965) 855-856.

= L. ZotZ: Altsteinzeitkunde Mitteleuropas. Ferdinand Enke Verlag, Stuttgart 1951.

= L. ZoTZ-W. VLK: Das Paläolithikum des unteres Waagtales. Quartär 2 (1939) 65-100. 